\title{
A review of the ethnomedicinal, antimicrobial, and phytochemical properties of Musa paradisiaca (plantain)
}

\author{
Kamoldeen Abiodun Ajijolakewu', Abiodun Saheed Ayoola1,2, Tariq Oluwakunmi Agbabiaka1, ${ }^{1 *}$ (D) \\ Folashade Rahmat Zakariyah', Nike Risikat Ahmed ${ }^{1}$, Olusegun Julius Oyedele ${ }^{2}$ and Alhasan Sani ${ }^{1}$
}

\begin{abstract}
Background: More people — in both developing and developed countries—now use, and are favourably disposed to, traditional medicine. Musa paradisiaca (plantain) is used extensively in traditional medicine across continents. In this review, we investigated the scientific justification of this extensive usage.

Main body: Generally, several studies validate usage in infectious diseases, but limited antiviral and in vivo reports exist. The mechanistic elicitation of antimicrobial activity has similarly not been ascertained. Contrarily, data abound from rigorous studies on physiological conditions. Activity across categories is tied to the potent phytosterols duo of stigmasterol and $\beta$-sitosterol; and the triterpenes viz. cycloeucalenone, 24-methylene-cycloartanol, and 31-norcyclolaudenone; present in plantain. Toxicity studies, while finite, suggest general safety and tolerance.
\end{abstract}

Conclusions: Findings in the studies reviewed projects plantain as a veritable source for drug bioprospecting that will be of benefit to scientific research and pharmaceutical industries.

Keywords: Musa paradisiaca, Plantain, Peel, Fruit, Antimicrobial, Phytochemicals, Extract, Medicinal, Activity

\section{Background}

The success of antibiotics against disease-causing microbes is one of the modern medicine's greatest achievements. Since the discovery of the first antibiotic from nature (mycophenolic acid) in 1893 by Bartolomeo Gosio from Penicillium glaucum (P. brevicompactum); synthesis of Salvarsan (arsphenamine) by Paul Ehrlich; and ultimately the serendipitous discovery of penicillin from Penicillium chrysogenum (previously $P$. notatum) by Alexander Fleming in 1928 (Nicolaou and Rigol 2018), healthcare delivery has significantly improved. An offtarget effect of these discoveries is that it also stimulated search for both prophylaxis and therapeutic agents. But before orthodox medicine, traditional medicine,

\footnotetext{
*Correspondence: tariqagbabiaka@gmail.com

${ }^{1}$ Department of Microbiology, Faculty of Life Sciences, University of Ilorin, PMB 1515, llorin, Nigeria

Full list of author information is available at the end of the article
}

primarily herbal medicine, held sway world over (Albertyn et al. 2015; Hosseinzadeh et al. 2015; Jaiswal et al. 2016; Li and Weng 2017). Traditional medicine, once regarded as quackery (Verpoorte 2017), and treated with scorn (Thomford et al. 2018), however, is making a resurgence (Amaeze et al. 2018) plausibly due to cost, limited and restricted access to orthodox treatment (Leonti and Casu 2013), antibiotic resistance (Blair et al. 2015), and perceived safety (Zhang et al. 2015) of herbal medicine due to its natural origin. An estimated $80 \%$ of population of the world utilise herbal medicines (Chatfield et al. 2018) with the sector valued at USD 100 billion (Zhang et al. 2015). This is testament of the renewed acceptance herbal medicine is enjoying.

Herbal medicine, in some nomenclature, also called phytomedicine (Bruno et al. 2018; Chatfield et al. 2018), relies on medicinal plants ( $\mathrm{Li}$ and Weng 2017), herbs (Thomford et al. 2018), roots (Chu et al. 2018), and fruits 
(Aune et al. 2017; Chatfield et al. 2018; Chu et al. 2018; Kipkore et al. 2014; Ożarowski et al. 2018; Shakib et al. 2019). While herbs, roots, their stems, rhizome, and barks are popular in traditional medicine, fruits and plants have a long history of application too (Kipkore et al. 2014; Nirumand et al. 2018). Medicinal fruits, also referred to as functional foods or nutraceuticals due to their perceived health benefit (Gul et al. 2016; PatiñoRodríguez et al. 2019), serve a dual role of dietary/nutritional and curative function (Pereira and Maraschin 2015). One of such fruit is plantain (Musa paradisiaca). This review highlights the antimicrobial, traditional, medicinal, along with the phytochemical constitution, usage of plantain while identifying current gaps.

\section{Description, distribution, and traditional uses}

Musa paradisiaca (common name: plantain) is an herbaceous (Arun et al. 2018; Ugbogu et al. 2018), perennial, monocotyledonous plant (Singh et al. 2016) belonging to the genus Musa along with (dessert) bananas (M. sapientum) (Pereira and Maraschin 2015) in the family Musacaceae (Ajiboye et al. 2018; Oyeyinka and Afolayan 2019; Ugbogu et al. 2018). These two are hybrids of $M$. acuminata (A) and M. balbisiana (B) giving them a polyploid nature with plantains containing majorly the genomes $\mathrm{AAB}, \mathrm{ABB}$, and $\mathrm{BBB}$ (Pereira and Maraschin 2015; Singh et al. 2016). The abaxial bract surface of plantains lacks papillae just like the adaxial epidermis which lacks calcium oxalate crystals that, otherwise, is present in bananas (Pereira and Maraschin 2015).

The plant is a tropical (Ajiboye et al. 2018; Imam and Akter 2011; Pereira and Maraschin 2015; Ugbogu et al. 2018) tree-like herb (Bagavan et al. 2011; Imam and Akter 2011; Lakshmi et al. 2015) that can grow to a height between $3 \mathrm{~m}$ (Imam and Akter 2011; Vilhena et al. 2019) and $15 \mathrm{~m}$ with an aerial pseudostem and submerged rhizome (Lakshmi et al. 2015) producing the large, pulpy, and starchy fruit (plantain) (Pereira and Maraschin 2015) with an elongated shape (Imam and Akter 2011) between 8 and $13 \mathrm{~cm}$ long (Mathew and Negi 2017).

While the plant is believed to be native to Southeast Asia, it is now cultivated extensively across both tropical and subtropical climates (Pelissari et al. 2012; Vu et al. 2018) including Nigeria (Eleazu et al. 2013; Tanee and Albert 2013; Yakubu et al. 2015) which ranks highest in West African production and sixth globally at 2.4 metric tonnes (Ekpete et al. 2017), while Central Africa is recognised for its great diversity of unique cultivars (Tsamo et al. 2014). In 2012 and 2013, global production stood at $118 \mathrm{mt}$ (Sartori and Menegalli 2016). This huge production is a testament of the importance of plantain as an important food crop coming behind only rice, wheat, and maize (Shamla and Nisha 2017) while being the most produced fruit accounting for a whopping $16.8 \%$ of fruits produced globally (Vu et al. 2018).

Apart from hybrids, cultivars are generally classified as French or Horn on the basis of the presence or otherwise of a male bud at maturity (Tsamo et al. 2015). The fruit, a pulp, differing from bananas in being starchy rather than sweet-tasting (Jiménez-Martínez et al. 2017), is a rich source of diverse nutrients and phytochemicals (Bennett et al. 2010; Jiménez-Martínez et al. 2017; Oyeyinka and Afolayan 2019; Pereira and Maraschin 2015; Shamla and Nisha 2017; Tsamo et al. 2015).

Thus, plantain can serve the dual purpose of dietary/ nutritional and therapeutic roles. Apart from the pulp, the peel, both ripe and unripe, which represents approximately $38 \%$ of the fruit in weight (Agama-Acevedo et al. 2016) similarly, is a phytochemical and nutrient repository (Behiry et al. 2019; Oyeyinka and Afolayan 2019; Silva et al. 2014) with further application as livestock feed and compost (Agama-Acevedo et al. 2016), and in biorefinery (Martínez-Ruano et al. 2018). Other parts of the plant, such as leaf, shoot, root, fruit, seed, inflorescence, and flower, are also receiving scientific attention (Kapadia et al. 2015; Correa et al. 2016; Lavanya et al. 2016; Mathew and Negi 2017).

These characteristics influence the use of plantain in folk medicine to cure both infectious and non-infectious diseases and wound healing (Amutha and Selvakumari 2016; Pereira and Maraschin 2015; Shodehinde and Oboh 2013; Vu et al. 2018).

\section{Antimicrobial properties}

In recognition of the role and importance of herbal medicine, World Health Organisation (WHO) has over the years carried out a number of strategic plans and passed resolutions aimed at improving the efficacy and quality of drugs of plant origin. The outcome of these has led to increased scientific inquiry into the basis and justification of their traditional uses (WHO 2013). One of the products of this endeavour is that since the release of the WHO's first series of Traditional Medicine Strategy (2002-2005), significant advances have been recorded in the scientific understanding of traditional and complementary medicine. This has had the knock-on effect of initiation and development of technical standards and guidelines for organised herbal health service delivery (WHO 2013).

There are a number of reports on antimicrobial activities of plantain (M. paradisiaca), and several organisms including fungi and bacteria with parasites and viruses enjoying lesser attention have been used as test organisms. Asoso et al. (2016) reported the antimicrobial activities of plantain peel and fruit extracts against Escherichia coli, E. coli ATCC 35218, Staphylococcus aureus, S. aureus 
ATCC 25923, Salmonella typhi, Salmonella typhi ATCC 22648, Salmonella typhi ATCC 23456, Shigella dysentriae ATCC 24162, Klebsiella pneumonia ATCC 34089, and Bacillus subtilis ATCC 21332 using agar well diffusion technique. Ethanolic extract of the peels had minimum inhibitory concentration (MIC) values between 150 and $200 \mathrm{mg} / \mathrm{mL}$ with the least being against $S$. aureus 25923 ATCC and the highest against Salmonella typhi 22648 ATCC and Klebsiella pneumonia 34089 ATCC. Ethanolic extracts of fruits had an MIC range of 200 and $300 \mathrm{mg} / \mathrm{mL}$. Methanolic extract of peels on the other hand ranged from $100 \mathrm{mg} / \mathrm{mL}$ to $200 \mathrm{mg} / \mathrm{mL}$, while methanolic extract of fruit yielded an MIC of $150 \mathrm{mg} /$ $\mathrm{mL}$ and $250 \mathrm{mg} / \mathrm{mL}$. Extracts of acetone from both peels and fruits had no activity against the test isolates. While activity was recorded, discrimination was not observed on the basis of cell wall Gram reaction suggesting that the mechanism of activity was by a route other cell wall lysis. The opportunistic skin pathogens, Propionibacterium acnes (Fitz-Gibbon et al. 2013; Perry and Lambert 2011) now known as Cutibacterium acnes (Dréno et al. 2018) and S. epidermidis (Taha et al. 2018), have been shown to be susceptible ethanolic extract of peel powder which makes it a potential antibacterial cosmetic agent. This potential usage is reinforced by Prakash et al. (2017) who reported inhibitory effect against Aspergillus niger now implicated in cases of Tinea capitis (Chokoeva et al. 2016).

In addition to bacteria, Jawla et al. (2012) challenged fungi with ethanolic and ethanolic and aqueous (1:1) extracts of $M$. paradisiaca flowers using the microdilution assay with MIC values of $5.62-25.81 \mu \mathrm{g} / \mathrm{mL}$ and $7.61-31.58 \mu \mathrm{g} / \mathrm{mL}$, respectively. Candida albidus MTCC-2661 had an MIC of 6.49 and $7.61 \mu \mathrm{g} / \mathrm{mL}$ for ethanolic and ethanolic and aqueous extracts, respectively. C. albicans MTCC-183 had marginally higher values at $8.62 \mu \mathrm{g} / \mathrm{mL}$ for ethanolic extracts and $9.88 \mu \mathrm{g} /$ $\mathrm{mL}$ for ethanolic and aqueous (1:1) extracts. Bacterial isolates Pseudomonas aeruginosa ATCC-9027, B. subtilis MTCC-121, and B. cereus MTCC-430 had ethanolic MIC of 5.62, 6.82, and $7.95 \mu \mathrm{g} / \mathrm{mL}$, while peak ethanolic MIC was observed with Salmonella typhimurium MTCC-98. E. coli MTCC-443 yielded peak MIC in ethanolic and aqueous (1:1) extracts with Streptococcus pneumoniae MTCC-2672 ranking below it at $24.86 \mu \mathrm{g} / \mathrm{mL}$ marginally ahead of Proteus mirabilis MTCC-1429 with $22.13 \mu \mathrm{g} /$ $\mathrm{mL}$. Generally, ethanolic extracts were active at lower concentration relative to ethanolic and aqueous (1:1) extracts an observation we attribute to a dilution effect of the water within the ethanolic and aqueous (1:1) extract. The authors went on to evaluate the acute and shortterm toxicity of extract on albino Wistar rat models with results indicating no toxicity and morbidity.
The limitation in this study, however, is that phytochemical assay was not done; thus, activity cannot be attributed to any phytochemical group which Ahmad et al. (2015) reported on. The authors reported the presence of glycosides, flavonoids, phenols, and saponins in ethanolic and methanolic extracts obtained via cold extraction. The aqueous extracts, however, lacked saponins.

Proximate analysis of flesh, peel, and peel aqueous extract by Oyeyinka and Afolayan (2019) reports the presence of fat, moisture, carbohydrates (which dominate at around $68 \%$ ), fibre, and minerals such as potassium, nitrogen, phosphorus, calcium, sodium, and magnesium in that order of quantity with trace elements such as zinc, copper, iron, and manganese present in minute quantities. Significantly, the graduation of quantity followed the same pattern in the pulp, peel, and peel extracts. Antinutrients, within WHO limits, such as phytate and oxalate were also present. This study proves the diversity of phytochemicals and nutrients inherent in plantain justifying its broad usage. A concern, however, is that the pulp is reported to severely interfere with absorption of quinolones with co-administration limiting the activity of ciprofloxacin against $E$. coli (Nwafor et al. 2003). This raises concern about drug interaction and influencing dynamics for which currently few, or no, data exist.

Chabuck et al. (2013) reported the antimicrobial effect of aqueous plantain peel extract. Aqueous extract of fresh yellow plantain peel was used to challenge two Grampositive (S. aureus and S. pyogenes) and four Gramnegative bacteria (Enterococcus aerogenes, Klebsiella pneumoniae, E. coli, and Moraxella catarrhalis) and a yeast isolate (Candida albicans). The aqueous extract of fresh plantain peel showed various inhibitory effects against the microbial isolates having the highest inhibitory effect against $M$. catarrhalis and S. aureus, followed by $S$. pyogenes, E. aerogenes, and K. pneumonia. However, no effect against $E$. coli and Candida albicans was observed implying intrinsic resistance.

Kapadia et al. (2015) evaluated the antimicrobial activity of alcoholic extract of plantain peel extract on the anaerobic Gram-negative periodontal pathogens Porphyromonas gingivalis and Aggregatibacter actinomycetemcomitans. The minimum inhibitory concentration, assessed using serial broth dilution method, showed that both $P$. gingivalis and $A$. actinomycetemcomitans had an MIC of $31.25 \mu \mathrm{g} / \mathrm{mL}$. The study, however, did not screen for phytochemical constituents nor run assays to determine mechanism of activity; thus, it is difficult to attribute an inhibitory pathway to the observation. However, observed activity can be attributed to the concerted inhibition by phytochemicals and ethanol which is inherently antimicrobial. 
The antimicrobial activity of hexane, ethyl acetate, and methanol extracts of leaves of some banana species, including M. paradisiaca, was reported by Karuppiah and Mustaffa (2013). To ascertain their antibacterial activities, E. coli, P. aeruginosa, Citrobacter species, and other bacteria which have been implicated in hospitalacquired infections (Mohammed et al. 2016; Tilahun et al. 2012; Zhang et al. 2017), were used as test organisms. The study revealed that ethyl acetate extracts were more potent than methanolic extract which in turn was better than hexane extract. Ethyl acetate extracts, however, had variable efficacy relative to chloramphenicol. $P$. mirabilis and E. aerogenes were resistant to hexane extracts. Significantly, the hexane extract had the highest MIC which ranged from 125.00 to $250.00 \mu \mathrm{g} / \mathrm{mL}$ followed by methanolic extract between 15.63 and $250.00 \mu \mathrm{g} / \mathrm{mL}$ with ethyl acetate ranking last between 15.63 and $125.00 \mu \mathrm{g} / \mathrm{mL}$. Hexane extract had a minimum bactericidal concentration of $250.00 \mu \mathrm{g} / \mathrm{mL}$, and ethyl acetate and methanolic extracts had a range between 31.25 and $250.00 \mu \mathrm{g} / \mathrm{mL}$. The generalised trend of bactericidal concentration was E. coli $<$ P. aeruginosa $<$ E. aerogenes $<K$. pneumoniae $<P$. mirabilis $<S$. flexneri $<$ Citrobacter sp. $<E$. faecalis $<S$. aureus. The authors attribute the activity observed to the presence of phenolic compounds, a theory valid from the results of their antioxidant activity which correlates directly. Significantly, M. paradisiaca had the most antioxidant activity with the order being $M$. paradisiaca $>M$. acuminata $>$ M. sapientum $>M$. troglodytarum. The only limitation with this study is that some extracts needed relatively high concentration to achieve inhibition or bactericidal activity which will necessitate a toxicity study to establish safety. Asuquo and Udobi (2016) reported that aqueous extracted performed better than ethanolic extract with an acute toxicity $\mathrm{LD}_{50}$ of $489.9 \mathrm{mg} / \mathrm{kg}$, suggesting that an effective dose may be toxic. In a similar study, Amutha and Selvakumari (2016) report the MIC of methanolic stem extract as $0.5 \mathrm{mg} / \mathrm{mL}$ for $P$. aeruginosa and $1.0 \mathrm{mg} / \mathrm{mL}$ for $S$. aureus with inhibition zone $(\mathrm{mm})$ ranking behind only gentamicin for $P$. aeruginosa and chloramphenicol and novobiocin for $S$. aureus.

Karadi et al. (2011) reported the in vitro antimicrobial activities of dichloromethane and methanol (1:1) extract of M. paradisiaca fruit peels against on E. coli, S. aureus, B. subtilis, $P$. aeruginosa, $C$. albicans, $C$. tropicalis, and $A$. niger using the agar well disc diffusion method. Results indicated that the extract of $M$. paradisiaca was more effective against the test isolates than the extract of Cocos nucifera.

Antifungal effects of plantain peel and stalk were examined by Okorondu et al. (2012) where A. niger, A. oryzae, and Rhizopus stolonifer were subjected to different concentrations $(1.00,0.50,0.25,0.125,0.0625 \mathrm{mg} / \mathrm{mL})$ of methanolic and ethanolic extracts of the peel and stalk. $A$. niger was more sensitive to both the peel and stalk extracts followed by $A$. oryzae and then $R$. stolonifer. Methanolic extracts yielded better activity relative to the ethanolic extract. Across both solvents, degree of inhibition of stalk extracts was correlated with concentration with $0.125 \mathrm{mg} / \mathrm{mL}$ MIC for $A$. niger, $0.25 \mathrm{mg} / \mathrm{mL}$ for $A$. oryzae, and $0.5 \mathrm{mg} / \mathrm{mL}$ for $R$. stolonifera. For peel extract, a different trend was observed with a methanolic MIC of $0.25 \mathrm{mg} / \mathrm{mL}$ A. niger and A. oryzae and $0.125 \mathrm{mg} / \mathrm{mL}$ for $R$. stolonifera. A. niger was $0.0625 \mathrm{mg} / \mathrm{mL}, 0.125 \mathrm{mg} /$ $\mathrm{mL}$ for $A$. oryzae, and $0.25 \mathrm{mg} / \mathrm{mL}$ for $R$. stolonifera. MIC for ethanolic extracts was pegged at $0.25 \mathrm{mg} / \mathrm{mL}$ for all isolates.

The test isolates are known food spoilage agents (dos Santos et al. 2012); thus, the results of the study suggest that the extracts of plantain peel and stalk, at appropriate concentrations, can be used in food preservation to prevent growth and spoilage by those spoilage fungi. A concern from the study, however, is that the authors identified the presence of cyanide and hydrogen cyanide, along with some phytochemicals, which could be an hazard (Tran et al. 2019) due to the associated adverse effects they are known to cause. The study also did not report on toxicity; thus, the safety of active concentrations-which is essential since its application is to be in food-cannot be ascertained.

While the majority of studies focus on extracts, Abdel Ghany et al. (2019), in an holistic study, investigated the activity of exudates of $M$. paradisiaca pseudostem against bacteria, fungi, and viruses. The exudate, also referred to as sap (Abdel Ghany et al. 2019) or mucilage (Galloway et al. 2020) sourced from conducting tissues (Zimmermann et al. 2013), is a viscous liquid, rich in organic molecules, capable of mediating plant physical and physiological responses (Galloway et al. 2020; Naveed et al. 2017) often, but not necessarily, produced in response to injury (Abdel Ghany et al. 2019; Zimmermann et al. 2013). Alkaloid, flavonoid, cardiac glycoside, anthraquinone, and phlobatannins were present in both methanolic and aqueous extracts of the exudates with only cardiac glycoside being absent in the aqueous extract. The exudate inhibited $S$. aureus and $E$. coli at low concentrations of $25 \mu \mathrm{L} / \mathrm{mL}$ and $50 \mu \mathrm{L} / \mathrm{mL}$ but Lactobacillus acidophilus, and $P$. aeruginosa required the relatively higher concentrations of $100 \mu \mathrm{L} / \mathrm{mL}$ and 200 $\mu \mathrm{L} / \mathrm{mL}$ for inhibition. The extract performed below the reference antibiotic ciprofloxacin. The authors, in one of the rare available reports on viruses, reported weak antiviral activity against hepatitis A virus (HAV-10) and significantly no activity against herpes simplex virus (HSV-1). Antifungal effect against both dermatophytes (Microsporum canis RCMB 0834 and Trichophyton 
mentagrophytes RCMB 092) and opportunistic (Cryptococcus neoformans RCMB 0049001; A. fumigatus RCMB 002008; C. tropicalis RCMB 005004 (1); and C. albicans RCMB 005003) showed that the exudate had no activity. An observation the authors noted is corroborated by Onyema et al. (2016) and Priya et al. (2014).

Following the increased attention plant-synthesised nanoparticles are receiving, Vijayakumar et al. (2017) reported the antibacterial activity of gold nanoparticles synthesised from the aqueous peel extract of plantain against multidrug-resistant biofilm community of E. faecalis MTCC 35550. Like other reports, the authors reported the presence of quinones, glycosides, tannins, phenols, flavonoids, essential oils, steroids, and phytosteroids which singly or collectively serves as reducing agent to chloroauric acid $\left(\mathrm{HAuCl}_{4}\right)$, thus mediating the synthesis of gold nanoparticles. At a dose-dependent rate, the agent inhibited the biofilm. Beyond $100 \mu \mathrm{g} /$ $\mathrm{ml}$, complete inhibition was reported as evidenced by the fragmentation of biofilm architecture. Relative to the nanoparticle, the $\mathrm{HAuCl}_{4}$ control had no activity. The authors putatively attribute activity to the ability of the nanoparticle to impair and prevent the synthesis of exopolysaccharide essential for biofilm formation. The activity of silver nanoparticles synthesised from plantain bract extract has similarly been reported as active against the plant pathogens Xanthomonas campestris, Clavibacter michiganensis, P. syringae, Burkholderia glumae, Alternaria alternata, Sclerotinia sclerotiorum, Macrophomina phaseolina, and Botrytis cinerea (Maruthai et al. 2018). The authors suggest that activity is attributable to the ability of the nanoparticle to induce oxidative stress, disrupt electron transport chain, and impede deoxyribonucleic acid (DNA) synthesis in bacteria, while antifungal activity is due to its ability to lysis cell membrane via membrane potential imbalance-due to the high degree of the nanoparticles' dispersion.

Accioly et al. (2012) reported the activity of $M$. paradisiaca (leaf) methanol 100\%, hexane/chloroform (50:50), ethylacetate/methanol (50:50), and ethylacetate/methanol (90:10) crude extracts against amastigotes and promastigotes of Leishmania chagasi, the causative organism leishmaniasis for which the epidemiology in Nigeria (Adediran et al. 2016) and indeed sub-Sahara Africa is poorly documented (Sunyoto et al. 2018). The best activity against promastigotes was observed in ethylacetate/methanol (90:10) and methanol $100 \%$ at an inhibitory concentration $(50 \%)\left(\mathrm{IC}_{50}\right)$ of 1.70 and $1.83 \mu \mathrm{g} / \mathrm{mL}$, respectively, while against amastigotes, ethylacetate/ methanol (90:10) and hexane/chloroform (50:50) had the best inhibitory activity at 14.18 and $15.07 \mu \mathrm{g} / \mathrm{mL}$, respectively. Observed activity was ascribed to the phytosterols like stigmasterol and $\beta$-sitosterol known to proliferate the activity of natural killer (NK) cells and T cells, alkaloids, tannins, anthocyanins, and phenolic compounds. This ascription is further reinforced by the infrared absorption bands of the hexane/chloroform (50:50) fraction peaked at hydrogen and $\mathrm{C}-13$ which is signatory of stigmasterol and $\beta$-sitosterol. Zhang et al. (2012) reported the $\mathrm{C}-14$ in cucumber and pumpkin stem exudates possessed activity. Another antiparasitic effect reported is anticoccidial activity. Anosa and Okoro (2011) report that at a dose-dependent rate, inhibition is observed with peak dose being $1000 \mathrm{mg} / \mathrm{kg}$ b.w. with no acute toxicity even at $4000 \mathrm{mg} / \mathrm{kg}$ b.w.

Silva et al. (2014) went further to evaluate, in vitro, the activity of three triterpenes (24-methylene-cycloartanol, cycloeucalenone, and 31-norcyclolaudenone) and a mixture of two sterols, namely stigmasterol and $\beta$-sitosterol, obtained, via column chromatography, from the ethanolic peel extract of unripe M. paradisiaca against Leishmania infantum chagasi promastigotes and amastigotes. Cycloeucalenone lacked activity, while the 24-methylene-cycloartanol, 31-norcyclolaudenone, and sterols exerted anti-promastigote effect with an effective concentration (50\%) $\left(\mathrm{EC}_{50}\right)$ of $16.55,39.29$, and $14.35 \mu \mathrm{g} / \mathrm{mL}$, respectively. Anti-amastigote $\mathrm{EC}_{50}$ of cycloeucalenone, 24-methylene-cycloartanol, and sterol mixtures was evaluated as $185,98.75$, and $126.5 \mu \mathrm{g} / \mathrm{mL}$, respectively. The individual activity of each of the sterols needs to be investigated to determine whether there is a synchronised or antagonistic activity in the current result. All the agents effected less toxicity to the mammalian LLCMK2 and RAW264.7 cells relative to the standard drug pentamidine with the order being 24-methylene-cycloartanol $<$ cycloeucalenone $<31$-norciclolaudenone $<$ sterol mixture for RAW264.7 cell and 24-methylene-cycloartanol $<31$-norciclolaudenone $<$ cycloeucalenone $<$ sterol mixture for LLC-MK2, suggesting that 24-methylenecycloartanol is the least toxic even though it is not the most efficacious. This implies that in vivo studies and dosing regimen are essential to build upon the current encouraging preliminary results. Table 1 summarises selected antimicrobial activity previously reported in the literature.

The broad spectrum of organisms susceptible to $M$. paradisiaca, its extracts, exudates, nanoparticles, and other scaffolds justify its utilisation in the management of diarrhoeal diseases. Putatively, our search identifies phytosterols (specifically stigmasterol and $\beta$-sitosterol) and the triterpenes, cycloeucalenone, 24-methylene-cycloartanol, and 31-norcyclolaudenone as the active metabolites mediating this broad range of activity. The structure of the compounds is provided in Fig. 1.

In addition to the antibiotic effect, it delayed the onset of diarrhoea; faecal water, its quantity, weight, and 


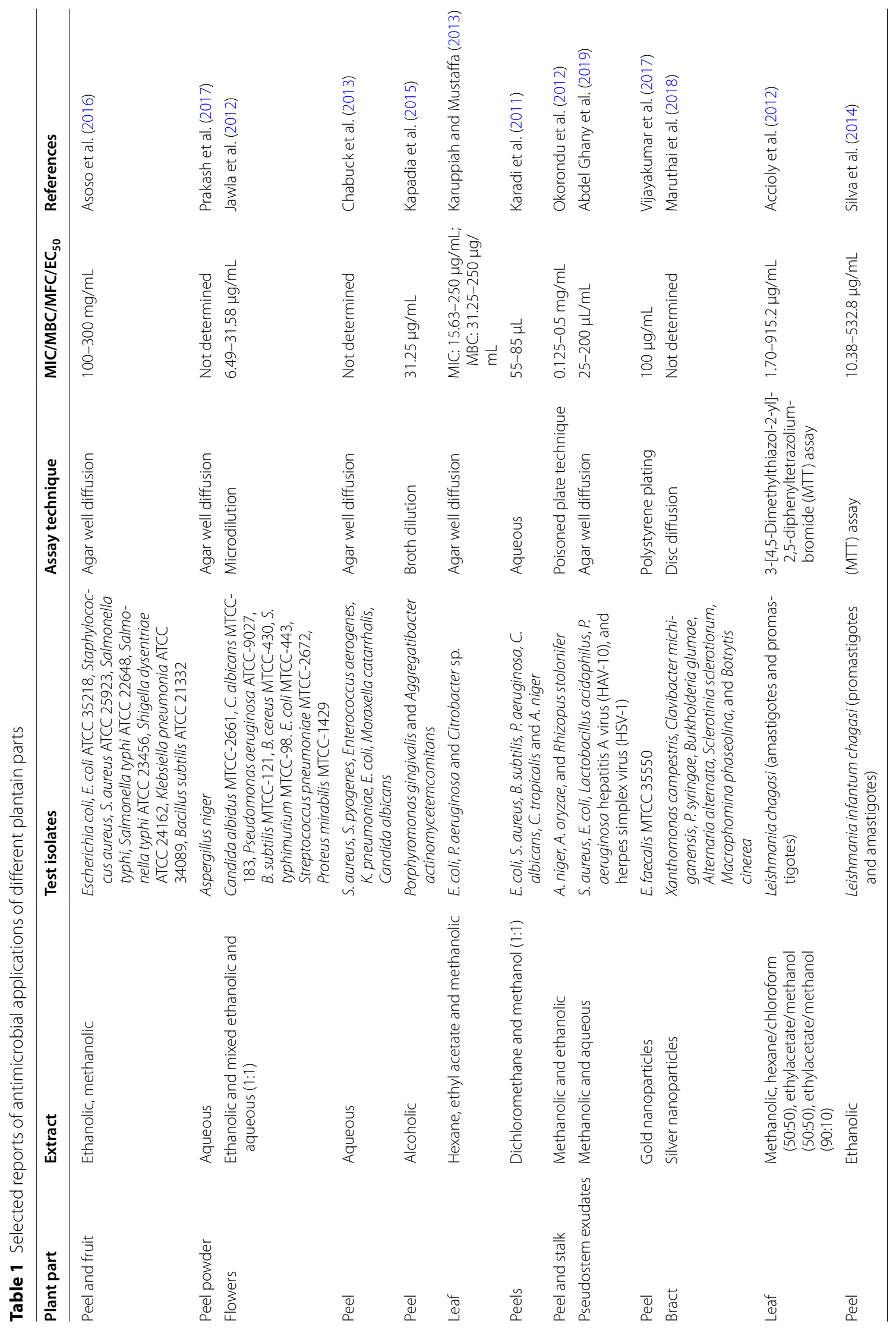


frequency; and improved electrolyte absorption (Yakubu et al. 2015). Since the antimicrobial activity exhibited by plantain is as a result of the embedded phytochemicals (Onyenekwe et al. 2013; Ehiowemwenguan et al. 2014), there is therefore a necessity to carry out extensive studies on how to maximally extract and process the useful phytochemicals into antimicrobials.

From these studies, empirical evidence of limited and, at other times, total (intrinsic) resistance of some test isolates suggests that the issue of antimicrobial resistance still exists. This lends credence to the claim (French 2010) that while abuse and misuse contribute significantly to antibiotic resistance, resistance is inherently an evolutionary survival scheme in the arsenal of microorganism; thus, the place of antibiotic pressure is significant only in speeding up the process. This creates a window for modification of agents into scaffolds to broaden the range, and thus efficacy, of available antimicrobials. The major variables influencing activity can have dynamic interaction (Fig. 2).

\section{Other medicinal properties}

Beyond antimicrobial application, plantain is traditionally used for other purposes (Correa et al. 2016).

\section{Wound healing}

A whopping $33.3 \%$ of traditional medicines are used in wound treatment and management majorly because of the accessibility, affordability, and safety (Accioly et al. 2012; Gebrehiwot et al. 2015). Traditionally, plantain is used in indigenous medicine, which the WHO estimates are used by $80 \%$ of the developed world's population (Asuquo and Udobi 2016), for wound healing (Amutha and Selvakumari 2016; Krishnan et al. 2014; Pereira and Maraschin 2015; Shodehinde and Oboh 2013) as a poultice (Agyare et al. 2009; Pereira and Maraschin 2015) which following the release of mediators of inflammation is followed by angiogenesis and fibroblast before it ends with the synthesis and remodelling of collagen fibres (Joshi et al. 2013; Murthy et al. 2013; Patil et al. 2012).

Consequently, it can be assumed that the phytochemical constituents of plantain can stimulate and mediate this process. Amutha and Selvakumari (2016) investigated this hypothesis using Wistar albino rat models inflict with red hot steel rod in hind limb region anaesthetised with ether. Treatment of the wound with methanolic extract of plantain stem resulted in faster wound healing relative to a control group treated with Vaseline. This was confirmed by comparing histopathological slides. This activity was attributed to the ability of the flavonoid content to, in addition to its antimicrobial activity, strengthen collagen fibres by increasing the fibrils' viability. The flavonoids, sterylacyl glycosides,
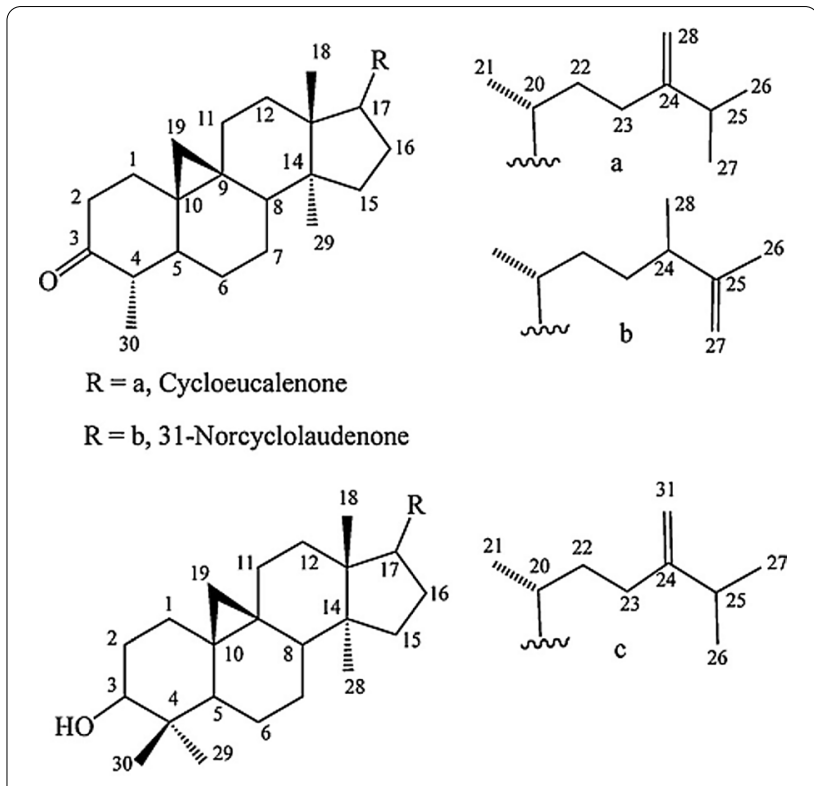

$\mathrm{R}=\mathrm{c}$, 24-methylenecycloartanol
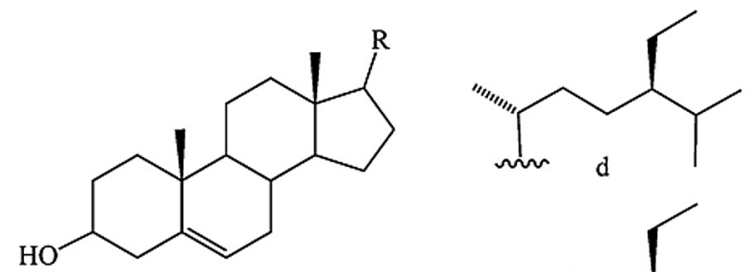

$\mathrm{R}=\mathrm{d}, \boldsymbol{\beta}$-sitosterol

$\mathrm{R}=\mathrm{e}$, Stigmasterol

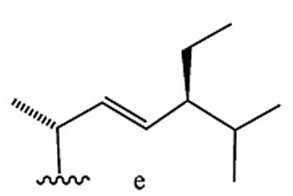

Fig. 1 Structure of putative phytosterols and triterpenes responsible for activity in M. paradisiaca (Silva et al. 2014)

and sitoindosides I-IV which are present in M. paradisiaca with sitoindoside IV which is known to recruit and amplify peritoneal macrophages and the general ability of flavonoids to limit the peroxidation of lipids are assumed to enhance normal wound healing (Alam et al. 2011; Patil et al. 2012). The antioxidant content of plantain extracts such as apigenin, shogaol, myricetin, isorhaemnetin, capsaicin, luteolin, caffeic acid, p-hydroxybenzoic acid, quercetin, kaempferol, glycitein, and gingerol (Fongnzossie et al. 2017) which have been severally reported (Abdel Ghany et al. 2019; Ahmad et al. 2015), can also play a part in the healing process (Pereira and Maraschin 2015). The synchronisation of physiological wound healing process with antimicrobial and immunological activity is logical as wounds are complex environment where microorganisms are active stakeholders (Joshi et al. 2013; Patil et al. 2012).

In the same vein, Mulukutla and Kale (2019) reported that autoclaved $M$. paradisiaca leaves were parallel in 
performance as dressing for facial abrasion relative to polyethylene surgical drape dressing (PESG).

\section{Anticancer activity}

Vijayakumar et al. (2017) reported that plantain peel aqueous extract-synthesised gold nanoparticles inhibited in vitro A549 lung cancer cells at a dose between 25 and $100 \mu \mathrm{g} / \mathrm{mL}$ significantly relative to DMSO, saline, peel extract, and $\mathrm{HAuCl}_{4}$ where peel extract performed better than other controls. $\mathrm{IC}_{50}$ was estimated at $58 \mu \mathrm{g} /$ $\mathrm{mL}$ with the apoptotic pathway assumed to be responsible for cytotoxic activity. This study provides a scientific justification for the use of $M$. paradisiaca in traditional management of cancer and allied inflammatory conditions (Correa et al. 2016; Krishnan et al. 2014; Pereira and Maraschin 2015).

Apart from lung cancer cell lines, the exudates of plantain pseudostem-which constitute around $31 \%$ of the plant mass (Saravanan and Aradhya 2011b) - have been shown to inhibit American Type Culture Collection (ATCC, Rockville, MD) strains of hepatocellular (HepG2) and human colon (HCT-116) carcinomas (Abdel Ghany et al. 2019). At an $\mathrm{IC}_{50}$ of $29.4 \mu \mathrm{L}, \mathrm{HepG}-2$ carcinoma was more sensitive with the highest cytotoxic effect to the cell lines which was observed at a dose of $100 \mu \mathrm{L}$.

A related activity to this is the antioxidant effect plantain has. Abdel Ghany et al. (2019) reported that via DPPH scavenging assay, exudate of plantain pseudostem elicited protective activity against free radicals on a concentration-dependent rate with a $\mathrm{IC}_{50}$ of $2.2 \mu \mathrm{L}$. This result suggests that the pseudostem can serve as prooxidant and antioxidant due to the tannins and polyphenols present in the extract. Padam et al. (2012), Karuppiah and Mustaffa (2013), Saravanan and Aradhya (2011a), and Saravanan and Aradhya (2011b) corroborate this result. Specifically, gallocatechin, dopamine in peels (Vijayakumar et al. 2017); (+)-catechin, gentisic acid, cinnamic, protocatechuic, ferulic, and caffeic acids (in pseudostem) (Saravanan and Aradhya 2011b); gallic, syringic, $\rho$-coumaric, and ferulic acids, and catechol (in inflorescence) (Arun et al. 2018) which are antioxidants, have been reported in M. paradisiaca. Apart from their ability to mitigate conditions resulting from reactive oxygen species, antioxidant effects are known to reduce the risk of cardiovascular and degenerative diseases and cancer (Saravanan and Aradhya 2011b). This provides a preliminary justification to search for bioactive agents in $M$. paradisiaca.

Apart from extracts, the essential oils derived from the fruit have been shown to possess antioxidant properties also. Fahim et al. (2019) reported that the essential oil obtained from the fruit contained $\alpha$-thujene, $\alpha$-pinene, sabinene, $\beta$-myrcene, $\alpha$-terpinene,
DL-limonene, tetradecanoic acid, $\alpha$-copaene, caryophyllene, $\beta$-bisabolene, isocaryophyllene, $\beta$-pinene, 1,2 -benzenedicarboxylic acid, hexadecanoic acid, 1-nonadecene, 6,9,12-octadecatrienoic acid which possess antioxidant, cytotoxic, and antitumour activity. This suggests that drugs and bioactive prospecting should not be restricted to only extracts or nanoparticles, and other fractions including essential oils can also be veritable sources.

A robust antioxidant effect from $M$. paradisiaca bract aqueous extract-mediated silver nanoparticles has also been reported (Maruthai et al. 2018). This implies that apart from serving as a pharmacologically active agent, it can similarly serve as a scaffold upon which other agents can be developed.

In a comparative study, Oyeyinka and Afolayan (2020) evaluated the antioxidant activity of aqueous, ethanol, and acetone extracts of plantain peel, boiled peel, and flesh. Via DPPH (2,2-diphenyl-1-picryl-hydrazyl-hydrate) assay, the boiled peel extract yielded the most antioxidant effect with the trend being: flesh aqueous extract $<$ flesh acetone extract $<$ peel ethanol extract $<$ peel acetone extract $<$ peel aqueous extract $<$ boiled peel extract at a dose of $0.01 \mathrm{mg} / \mathrm{mL}$. A different trend, using the ferric reducing ability of plasma (FRAP) assay, being peel acetone extract $<$ flesh aqueous extract $<$ flesh acetone extract $<$ boiled peel extract $<$ flesh ethanol extract $<$ peel aqueous extract $<$ peel ethanol extract at the same dose $(0.01 \mathrm{mg} / \mathrm{mL})$ was observed. The 2,2'-azino-bis(3-ethylbenzothiazoline-6-sulfonic acid) (ABTS) radical scavenging assay yielded the order flesh aqueous extract $<$ flesh ethanol extract $<$ flesh acetone extract $<$ peel acetone extract $<$ peel ethanol $<$ peel aqueous extract $<$ boiled peel extract, while the inhibitory activity yielded the same pattern except that flesh acetone extract $<$ flesh ethanol extract. This result suggests that care should be taken when comparing the antioxidant activities evaluated using different techniques as they may yield different results and context will be necessary for comparison. For ABTS inhibition assay, the peak concentration of $0.08 \mathrm{mg} / \mathrm{mL}$ with acetone extract, among other extracts, yielded the most activity, while the peel, among other parts, yielded the most activity. Significantly, this result suggests that, at some concentrations, aqueous and acetone extracts can cause prooxidant effects to generate free radicals and/or inhibit antioxidant activity. This means that care should be taken in selection of concentrations and choice of solvent during indigenous management of diseases involving plantain.

Antioxidant activity is not restricted to only the ripe fruit as Shodehinde and Oboh (2013) report that aqueous extracts of raw, boiled, roasted, and elastic paste derived from green, unripe plantain and further processed into flours exhibited antioxidant effects in vitro 


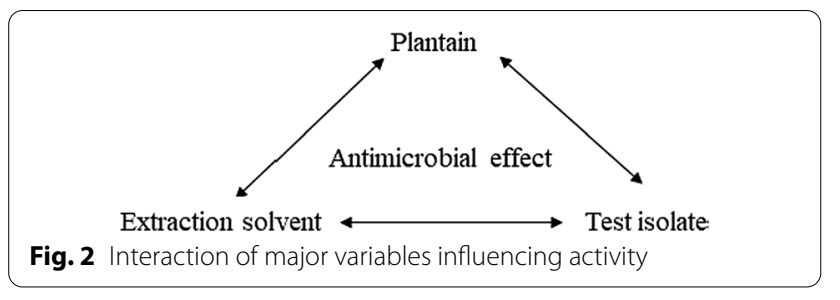

on the pancreas of rats and in plasma (Shodehinde et al. 2015). This suggests that these pretreatment methods do not eliminate the antioxidant capability of the unripe fruit; thus, the antioxidant contents may be regarded as stable and resilient. This stand appears to be validated by Sasipriya et al. (2014), even suggesting that the treatments enhanced phenolics and tannins content by up to threefold and fivefold, respectively. While this is true, Ibukun et al. (2012) report that ripening has a degrading effect on the polyphenolic content of plantain pulp and its antioxidant activity on hepatic and cerebral tissues of male murine models though Tsamo et al. (2014) posit that upon stage 5 ripening, an increase in phenolic content precedes this reduction. The unripe pulp extracts are regarded as possessing better antidiabetic effect over overripe and ripe pulp extract (Bhinge et al. 2019).

Arun et al. (2018) reported on an in vitro cytotoxic activity of inflorescence of plantain, which relative to other parts is less studied, against the HT29 human colon cancer-the third most common cancer across world. The methanolic extract was reported to cause cell cycle arrest and initiation of both intrinsic and extrinsic apoptotic pathways. At a dose dependent rate, effect was amplified. An estimated $\mathrm{IC}_{50}$ of $259.84 \mu \mathrm{g} / \mathrm{mL}$ and $130.26 \mu \mathrm{g} /$ $\mathrm{mL}$, respectively, for ethyl acetate and methanolic extract via the MTT assay and $268.62 \mu \mathrm{g} / \mathrm{mL}$ and $195.31 \mu \mathrm{g} / \mathrm{mL}$ via the LDH release assay was reported. The methanolic extract, on this metrics, had better anticancer activity which was presumably attributed to the polyphenolic contents. After $24 \mathrm{~h}$, DNA damage and apoptotic changes in HT29 were observed by cell cycle arrest at phase $\mathrm{G} 2 / \mathrm{M}$, a process mediated by cyclin proteins. The authors suggest that apart from polyphenols, they may be other bioactive compounds that induce and regulate the expression of cyclin proteins to effect cell arrest. Disintegration of mitochondrial membrane and loss of cytochrome $\mathrm{c}$ and an ultimate reduction in energy generation were similarly observed just as BCL2 anti-apoptotic protein expression was reduced with the converse true for pro-apoptotic BAX while cleaving PARP and caspase 3. It was concluded that these concerted activity leads to apoptosis. The expression pattern of other proteins such as GRP78, calreticulin, CSN, PDH complex, POLR2C, PRDX6, SLC25A35, and X-linked inhibitor of apoptosis, however, in this study, in the context of other reports, was unsettled, suggesting the necessity of further study to conclusively tie their expression pattern to specifics. Extracts of the inflorescence have also been reported to possess cytotoxic effect on cervical cancer cells in a pathway that implicates caspase-9 (Nadumane and Timsina 2014) and malignant melanoma (Sundaram et al. 2018). Human oral squamous cell carcinoma (OSCC) cell lines (HSC-4) are another carcinoma susceptible to plantain extract (Abd Ghafar et al. 2019). The supernatants obtained from a co-fermentation by Lactobacillus casei and Bifidobacterium bifidum of soluble dietary fibresknown to aid prevention of physiological diseases such as irritable colon, constipation, diverticulosis, diabetes, cardiovascular diseases, and colon cancer (Pathak et al. 2016) - in the inflorescence and further enriched with short-chain fatty acids possess cytotoxic effect on colorectal cancer cells (HT29) by triggering apoptotic pathways (Arun et al. 2019). Consequently, beyond extracts, fermented products of plantain may, in addition to being nutritional sources, be a nutraceutical source of bioactive antitumour agents.

Harsha Raj et al. (2017) report that ethyl acetate extract of plantain roots, in in vitro and in vivo assays, demonstrated pro-apoptotic and anti-angiogenic activity against the severely metastatic and aggressive dual invasive ductal breast cancer cell lines (MCF-7 and MDAMB-231) and human umbilical vein endothelial cells (HUVEC). Via a MTT assay, an $\mathrm{IC}_{50}$ of $60 \mu \mathrm{g} / \mathrm{mL}$, significantly lower than that reported by Arun et al. (2018) at $259.84 \mu \mathrm{g} / \mathrm{mL}$ with $20 \mu \mathrm{g} / \mathrm{mL}$ yielding a DNA synthesis decrease of $61.6 \%$ for HUVEC, $71 \%$ for MCF-7, and $75 \%$ in for MDA-MB-231 demonstrating its cytotoxic effect by suppressing angiogenesis by $76 \%$. In the murine models, a reduction of $50 \%$ suggests anticancer effect. This result is significant in that it adds anti-angiogenic activity to one of the mechanisms that plantain extracts mediate anticancer activity via rigorous data validation by several in vitro and in vivo assays. The cytotoxic effect of (methanolic) extracts of plantain roots has similarly been corroborated via the brine shrimp lethality test (Chowdhury et al. 2016).

\section{Antidiabetic activity}

The use of plantain in indigenous management of diabetes with a high global burden (Meigs 2019), more so in Africa (Tekola-Ayele et al. 2013) where health institutions reel under several strains, necessitates the investigation of the scientific justification.

Aqueous extracts and methanolic fractions of M. paradisiaca flowers and bract produced antidiabetic effect in male Wistar rats experimentally induced diabetes using intravenous streptozotocin (STZ). Of the lot, methanolic fractions of the flower yielded the best glucose 
tolerance effect, after treatment for 15 days, with aqueous extract of the bract following closely comparable to insulin treatment. All the extracts and fractions, however, had improvement relative to the untreated control group due to the presence of flavonol glycoside and anthocyanins in the fractions and extracts which have severally been shown to possess anti-hyperglycaemic activity (Vilhena et al. 2020). The authors recommend the aqueous bract extract over methanolic fraction due to the ease of obtaining aqueous extracts over methanolic fractions. Jawla et al. (2012) corroborate the antidiabetic effect of flower extract within a week. Arun et al. (2017) validate the antidiabetic activity of methanolic flower extract attributable to the polyphenolic compound and dietary fibres present, thus backing calls for the exploration of inflorescence as a potential functional food and/or nutraceutical (Lau et al. 2020) with excellent nutritional and organoleptic properties (Adelekan et al. 2019).

Other than extracts and fractions, Shodehinde et al. (2015) report that unripe pulp of $M$. paradisiaca reduced blood glucose levels by inhibiting intestinal $\alpha$-glucosidase, pancreatic $\alpha$-amylase, and angiotensinI-converting enzyme (ACE) in experimentally diabetic adult male Wistar rats after 14 days of oral administration due to the polyphenolic content. Syringin $(50 \mathrm{mg} / \mathrm{kg}$ body weight) isolated from the ethanolic extract of plantain flower reversed diabetic indices in experimentally diabetic rats, upon oral administration with no observable acute toxicity after 30 days. It is hypothesised that syringin, a phenyl-propanoid glucoside with the chemical formula 4-[(1E)-3-hydroxyprop-1-en-1-yl]-2,6-dimethoxyphenyl-D-glucopyranoside, acts by maintenance of glucose homeostasis and C-peptide levels (Krishnan et al. 2014). It has also been suggested that anti-hyperglycaemic activity may also be mediated by the down-regulation of the inflammatory cytokines TNF- $\alpha$ and IL- $1 \beta$ while up-regulating the titres of transforming growth factor- $\alpha$ (TGF- $\alpha$ ) in Inbred Charles-Foster albino rats induced with STZ-induced diabetes administered (orally) with $100 \mathrm{mg} / \mathrm{kg}$ of the ethanolic extract of unripe fruit (Kumar et al. 2013). These hypotheses have been reiterated by Abdel Aziz et al. (2020) though activity was attributed to phytol, stigmasterol, $\beta$-sitosterol, and vitamin $\mathrm{E}$.

Via a diet-based therapy, Famakin et al. (2016) report that plantain-based dough meals-supplemented with cassava fibre and soybean cake-resulted in lower blood glucose, implying that a plantain-based diet, in addition to chemotherapy, can successfully manage the condition though the concern about interaction will need to be addressed. The rich content of the micronutrients potassium and sodium in plantain has also been suggested as responsible for this effect due to their fundamental role in metabolism, bodily fluids and structural tissues composition. Results from Ajiboye et al. (2018) and Oluwajuyitan and Ijarotimi (2019) support the use of plantain-based diet in the management of diabetic and related dyslipidemic conditions.

Other reports have supported the claimed antidiabetic effect of plantain (Eleazu et al. 2013, 2016), its extracts (Kappel et al. 2013; Navghare and Dhawale 2017; Reddy and Hemachandran 2014; Shanmuga and Subramanian 2012), and nanoparticles (Anbazhagan et al. 2017) using different parts (Vilhena et al. 2018; Parmar and Kar 2008).

\section{Antiulcer activity}

In other medicinal effects explained earlier, it has been shown that plantain has, in addition to these activities, a corresponding antiulcer in models with co-infection. Diabetes is known to be associated with gastric ulcer (Boehme et al. 2007); thus, Kumar et al. (2013) reported that methanolic extract of plantain pulp elicited antiulcerative effects in diabetic rats. Oral administration of $100 \mathrm{mg} / \mathrm{kg}$ resulted in remediated ulcer area by increasing the titre of TGF- $\alpha$, suggesting that activity is related to promoting TGF expression due to the flavonoid content which is supported by others (Alese et al. 2017; Loganayaki et al. 2010; Yakubu et al. 2015). The upregulation is tempered by a yet unknown process, implying that further studies ought to modify the formulation to eliminate this diminishing effect. Vadivelan et al. (2006) suggest that micronutrients and minerals play a role in the attenuation of ulcer index, improved mucus barrier, and regulation of non-protein sulfhydryl group. This mechanism along with thickening of mucosal epithelium and collagen deposition has been substantiated by others (Alese et al. 2018). Apart from flavonoids, syringin, a phenylpropanoid glucoside isolated from $M$. paradisiaca flower, is reported to be active in ulcer treatment (Krishnan et al., 2014).

The antiulcer activity of plantain does not appear to be related to the inhibition of Helicobacter pylori which is implicated in gastric ulcer (Goel et al. 2001; Kumar et al. 2013). On the other hand, ethanolic extract of the pseudostem, at a dose-dependent scale, decreased the acidity of gastric juice without an effect on secreted volume (Khamboonruang et al. 2015). The same has been said of the methanolic extract of unripe $M$. paradisi$a c a$ as well as interacting with epidermal growth factor receptor (EGFR) and mediating an elevated expression of PECAM-1, a protein angiogenesis and cell adhesion (Alese et al. 2017) pointing to the possibility of an angiogenetic pathway in gastric ulcer healing in murine models.

Table 2 summarises some reported traditional and medicinal properties. 
Table 2 Comparative analyses of traditional and medicinal applications of plantain parts

\begin{tabular}{|c|c|c|c|c|c|}
\hline Application & Part used & Extraction method & Dose (mg/kg) & Effects/findings & References \\
\hline Antidiarrhoeal & Pulp & Flaked & - & $\begin{array}{l}\text { Reduces/stops diarrhoea; } \\
\text { thus an effective antidi- } \\
\text { arrhoeal agent }\end{array}$ & $\begin{array}{l}\text { Rabbani et al. (2001), } \\
\text { Debaandya and Namrata } \\
\text { (2010) }\end{array}$ \\
\hline Antidiabetic & Pulp & Ethanolic & $100-800$ & $\begin{array}{l}\text { Reduces blood glucose } \\
\text { concentration; has } \\
\text { antidiabetic effect }\end{array}$ & Singh et al. (2007) \\
\hline Antiulcer & Pulp & $\begin{array}{l}\text { Ethanolic, aqueous; } \\
\text { methanolic }\end{array}$ & 500 & $\begin{array}{l}\text { Decreases gastric juice; } \\
\text { effective against ulcer }\end{array}$ & $\begin{array}{l}\text { Goel et al. (2001), Pannang- } \\
\text { petch et al. (2001) }\end{array}$ \\
\hline Antioxidant & Pulp & Methanolic & - & $\begin{array}{l}\text { Reverses increased lipid } \\
\text { peroxidation; a good } \\
\text { antioxidant }\end{array}$ & Goel et al. (2001) \\
\hline Cholesterol lowering & Pulp, peel; root & $\begin{array}{l}\text { Freeze-dried, dried; } \\
\text { methanolic }\end{array}$ & $100-500$ & $\begin{array}{l}\text { Corrects histopatho- } \\
\text { logical/biochemical } \\
\text { imbalances; a good } \\
\text { cholesterol normalising } \\
\text { agent }\end{array}$ & $\begin{array}{l}\text { Mallick et al. (2006), Parmar } \\
\text { and Kar (2008), Vijayaku- } \\
\text { mar et al. (2008) }\end{array}$ \\
\hline Liver/kidney protection & Pulp, peel, root; stem & Ethanolic; aqueous & $200-500$ & $\begin{array}{l}\text { Reversed and normalise } \\
\text { liver and kidney func- } \\
\text { tions; ability to protect } \\
\text { liver and kidney }\end{array}$ & $\begin{array}{l}\text { Iweala et al. (2011), Nirmala } \\
\text { et al. (2012), Oyewole } \\
\text { et al. (2015) }\end{array}$ \\
\hline $\begin{array}{l}\text { Hair growth and skin } \\
\text { protection }\end{array}$ & Pulp; stem & Aqueous & - & $\begin{array}{l}\text { Promotes healthy skin } \\
\text { and hair; protects skin } \\
\text { and hair }\end{array}$ & $\begin{array}{l}\text { Rojas et al. (2006), Savali } \\
\text { et al. (2011), Kumar et al. } \\
\text { (2012) }\end{array}$ \\
\hline $\begin{array}{l}\text { Blood clotting and } \\
\text { wound healing }\end{array}$ & Pulp; stem & Methanolic; aqueous & - & $\begin{array}{l}\text { Reduces bleeding \& } \\
\text { clotting times; pos- } \\
\text { sesses haemostatic } \\
\text { and wound healing } \\
\text { properties }\end{array}$ & $\begin{array}{l}\text { Agarwal et al. (2009), Novak } \\
\text { et al. (2003), Weremfo } \\
\text { et al. (2011) }\end{array}$ \\
\hline Antihypertensive & Pulp & Dried & - & $\begin{array}{l}\text { Lowers mean arterial } \\
\text { blood pressure to } \\
\text { normal; capable of } \\
\text { normalising blood } \\
\text { pressure }\end{array}$ & Osim and Ibu (1991) \\
\hline
\end{tabular}

Table 3 Phytochemical composition of plantain

\begin{tabular}{|c|c|c|c|c|}
\hline \multirow[t]{2}{*}{ Phytochemicals } & \multicolumn{4}{|c|}{ Values (mg/100 g) } \\
\hline & Peel & Leaf & Flower & References \\
\hline Tannins & 28.4 & 115 & 88.31 & Adeolu and Enesi (2013), Akinsanmi et al. (2015) \\
\hline Saponin & 327 & 563.33 & 1430 & Adeolu and Enesi (2013), Akinsanmi et al. (2015) \\
\hline Phenols & 89.4 & 4.5 & 5.83 & Adeolu and Enesi (2013), Akinsanmi et al. (2015) \\
\hline Flavonoids & 1.0 & 145 & 3.98 & Adeolu and Enesi (2013), Akinsanmi et al. (2015) \\
\hline Alkaloids & - & 24 & 156 & Adeolu and Enesi (2013) \\
\hline
\end{tabular}

\section{Effect of extraction technique and solvent on extract}

The technique of extraction (Correa et al. 2016; Do et al. 2014; González-Montelongo et al. 2010; Monteiro et al. 2020; Pietrzak et al. 2014; Waszkowiak et al. 2015) and solvents (Correa et al. 2016; Do et al. 2014; Monteiro et al. 2020) has impact on the phytochemical constituents obtained from M. paradisiaca and consequently its bioactive activity (Correa et al. 2016;
González-Montelongo et al. 2010). The pharmacological action of plantain is mostly attributed to the phenolic content which polar solvents are best suited for extracting (Do et al. 2014; Monteiro et al. 2020). This may explain why most studies utilised polar solvents. Of the lot, methanolic extracts appear to be the most active.

Heat, also, appears to be a critical factor. GonzálezMontelongo et al. (2010) report that elevated 
Table 4 Nutritional compositions of plantain

\begin{tabular}{lllll}
\hline Phytochemicals & \multicolumn{2}{l}{ Values $\mathbf{( m g / 1 0 0 ~ g ) ~}$} & Pulp & References \\
\cline { 2 - 4 } & Peel & Leaf & 2.0 & Adeolu and Enesi (2013), Akinsanmi et al. (2015), United \\
\hline Sodium & 162 & 280 & & States Department of Agriculture (2018) \\
Potassium & 235 & 40 & 431 & Adeolu and Enesi (2013), Akinsanmi et al. (2015), USDA (2018) \\
Calcium & 100 & 135 & 2.0 & Adeolu and Enesi (2013), Akinsanmi et al. (2015), USDA (2018) \\
Magnesium & 76 & 18 & 41 & Adeolu and Enesi (2013), Akinsanmi et al. (2015), USDA (2018) \\
Iron & 5.6 & 14 & 0.75 & Adeolu and Enesi (2013), Akinsanmi et al. (2015), USDA (2018) \\
Phosphorus & 360 & 151.67 & 31 & Adeolu and Enesi (2013), Akinsanmi et al. (2015), USDA (2018) \\
Zinc & - & - & 0.18 & USDA (2018) \\
Vit. C & 11.72 & 8.17 & 20.2 & Adeolu and Enesi (2013), Akinsanmi et al. (2015), USDA (2018) \\
Vit. A & - & 0.97 & - & Adeolu and Enesi (2013) \\
Thiamine & - & 0.20 & 0.10 & Adeolu and Enesi (2013), USDA (2018) \\
Riboflavin & - & 0.50 & 0.10 & Adeolu and Enesi (2013), USDA (2018) \\
Niacin & - & 1.13 & 0.55 & Adeolu and Enesi (2013), USDA (2018) \\
Vit. B6 & - & - & 0.07 & USDA (2018) \\
Protein & $11.47^{*}$ & - & Adeolu and Enesi (2013), USDA (2018) \\
Fibre & $8.47^{*}$ & - & Adeolu and Enesi (2013), USDA (2018) \\
Carbohydrate & $60.87^{*}$ & - & Adeolu and Enesi (2013), USDA (2018) \\
\hline
\end{tabular}

Values with asterisk $(*)$ are in grams (g)

temperature improved extraction efficiency and solubility of phytochemical constituents but can cause degradation of volatile constituents just as Correa et al. (2016) asserts that with supercritical $\mathrm{CO}_{2}$ extraction yield is lowered with the converse true for propane. This seems to suggest that there is a complex association between temperature and solvent that require elucidation.

The wide range of extraction technique reported and the variations makes comparison difficult since this influences phytochemical content and eventually its activity. This leads us to call for a standardisation of extraction protocol (to serve as baseline) that can be compared with other optimised protocols.

A list of some of the phytochemical and nutrient components of $M$. paradisiaca is presented in Tables 3 and 4 , respectively.

\section{Conclusions}

Different parts of $M$. paradisiaca have been studied extensively and found to modulate physiological activities and antimicrobial effects on various microorganisms. However, as against most of the conventional antimicrobials used in pharmacological and cosmetics preparations, the mechanisms of actions of this potent antimicrobial and medically active plant on each of the applications have not been well studied. Similarly, while antimicrobial-generally_studies are extensive, limited antiviral and in vivo reports exist. Putatively, the bioactive metabolites that appear to mediate antimicrobial activity are stigmasterol and $\beta$-sitosterol (phytosterols) and the triterpenes trio of 31-norcyclolaudenone, 24-methylene-cycloartanol, and cycloeucalenone. The paucity of in vivo and antiviral studies are gaps that require to be earnestly. As for physiological conditions, extensive and rigorous studies abound which begs the question of why a formal drug development scheme from $M$. paradisiaca has not been pursued by pharmas in this regard.

Isolation, purification, and characterisation of the active ingredients, apart from syringin, from M. paradisiaca are also necessitated to potentiate its exploitation. Finally, while there is paucity of data in toxicity studies where there are, they have been deemed to be highly tolerated and safe.

\footnotetext{
Abbreviations

ABTS: 2,2'-Azino-bis(3-ethylbenzothiazoline-6-sulfonic acid); ACE: AngiotensinI-converting enzyme; DNA: Deoxyribonucleic acid; DPPH: 2,2-Diphenyl-1-picryl-hydrazyl-hydrate; $\mathrm{EC}_{50}$ : Effective concentration; EGFR: Epidermal growth factor receptor; FRAP: Ferric reducing ability of plasma; $\mathrm{HAuCl}_{4}$ : Chloroauric acid; HAV: Hepatitis A virus; HSV: Herpes simplex virus; HUVEC: Human umbilical vein endothelial cells; $I_{50}$ : Inhibitory concentration; MIC: Minimum inhibitory concentration; NK: Natural killer; OSCC: Oral squamous cell carcinoma; STZ: Streptozotocin; WHO: World Health Organisation.
}

\section{Acknowledgements}

Not applicable. 


\section{Authors' contributions}

AKA, ASA, TOA, FRZ, NRA, and AS reviewed studies on antimicrobial activities. OJO reviewed antidiabetic studies and mineral content. ASA wrote the initial draft. TOA reviewed the initial draft; description, distribution, and traditional uses; antimicrobial activities and other medicinal properties and wrote the manuscript to make the current structure. All authors read and approved the final manuscript.

\section{Funding}

The authors did not receive any funding from external sources.

\section{Availability of data and material}

Not applicable.

\section{Declarations}

Ethics approval and consent to participate

Not applicable.

\section{Consent for publication}

Not applicable.

\section{Competing interests}

The authors declare that they have no competing interests.

\section{Author details}

${ }^{1}$ Department of Microbiology, Faculty of Life Sciences, University of Ilorin, PMB 1515, Ilorin, Nigeria. ${ }^{2}$ Bioresources Development Centre, National Biotechnology Development Agency, Ogbomosho, Oyo State, Nigeria. ${ }^{3}$ Microbiology Unit, Department of Science Laboratory Technology, School of Science and Technology, Federal Polytechnic, Damaturu, P.M.B. 1006, Damaturu, Yobe State, Nigeria.

Received: 10 February 2021 Accepted: 27 April 2021

Published online: 08 May 2021

\section{References}

Abd Ghafar SA, Hasan Fikri I, Eshak Z (2019) Antioxidant activity of Musa paradisiaca (banana) soft pith and its cytotoxicity against oral squamous carcinoma cell lines. Malays J Med Health Sci 3:8-11

Abdel Aziz SM, Ahmed OM, Abd El-Twab SM, Al-Muzafar HM, Amin KA, AbdelGabbar M (2020) Antihyperglycemic effects and mode of actions of Musa paradisiaca leaf and fruit peel hydroethanolic extracts in nicotinamide/streptozotocin-induced diabetic rats. Evid Based Complement Altern Med 2020:9276343. https://doi.org/10.1155/2020/9276343

Abdel Ghany TM, Ganash M, Alawlaqi MM, Al-Rajhi AMH (2019) Antioxidant, antitumor, antimicrobial activities evaluation of Musa paradisiaca $\mathrm{L}$. pseudostem exudate cultivated in Saudi Arabia. BioNanoScience 9:172-178. https://doi.org/10.1007/s12668-018-0580-x

Accioly MP, Bevilaqua CM, Rondon FC, de Morais SM, Machado LK, Almeida CA, de Andrade Jr HF, Cardoso RP (2012) Leishmanicidal activity in vitro of Musa paradisiaca L. and Spondias mombin L. fractions. Vet Parasitol 187(1-2):79-84. https://doi.org/10.1016/j.vetpar.2011.12.029

Adediran OA, Kolapo TU, Uwalaka EC (2016) Seroprevalence of canine leishmaniasis in Kwara, Oyo and Ogun states of Nigeria. J Parasit Dis 40:510-514. https://doi.org/10.1007/s12639-014-0535-2

Adelekan EO, Adegunwa MO, Adebowale AA, Bakare HA, Alamu EO (2019) Quality evaluation of snack produced from black pepper (Piper nigrum L.), plantain (Musa paradisiaca L.), and tigernut (Cyperus esculentus L.) flour blends. Cogent Food Agric 5:1614285

Adeolu A, Enesi D (2013) Assessment of proximate, mineral, vitamin and phytochemical compositions of plantain (Musa paradisiaca) bract-an agricultural waste. Int J Plant Sci 4:192-197

Agama-Acevedo E, Sañudo-Barajas JA, Vélez De La Rocha R, González-Aguilar GA, Bello-Peréz LA (2016) Potential of plantain peels flour (Musa paradisiaca L.) as a source of dietary fiber and antioxidant compound CyTA. J Food Sci 14:117-123. https://doi.org/10.1080/19476337.2015.1055306
Agarwal PK, Singh A, Gaurav K, Goel S, Khanna HD, Goel RK (2009) Evaluation of wound healing activity of extracts of plantain banana (Musa sapientum var. paradisiaca) in Rats. Indian J Exp Biol 47:322-340

Agyare C, Asase A, Lechtenberg M, Niehues M, Deters A, Hensel A (2009) An ethnopharmacological survey and in vitro confirmation of ethnopharmacological use of medicinal plants used for wound healing in Bosomtwi-Atwima-Kwanwoma area. Ghana J Ethnopharmacol 125:393-403. https://doi.org/10.1016/j.jep.2009.07.024

Ahmad BA, Mohd KS, Abdurrazak M, Rao UM, Zin T (2015) Phytochemical screening, antioxidant activity of pure syringin in comparison to various solvents extracts of Musa paradisiaca (banana)(fruit and flower) and total phenolic contents. Int J Pharm Pharm Sci 7:242-247

Ajiboye BO, Oloyede HOB, Salawu MO (2018) Antihyperglycemic and antidyslipidemic activity of Musa paradisiaca-based diet in alloxan-induced diabetic rats. Food Sci Nutr 6:137-145. https://doi.org/10.1002/fsn3.538

Akinsanmi AO, Oboh G, Akinyemi JA, Adefegha AS (2015) Assessment of the nutritional, anti nutritional and antioxidant capacity of unripe, ripe and over ripe plantain (Musa paradisiaca) peels. J Adv Res 3:63-72

Alam G, Singh MP, Singh A (2011) Wound healing potential of some medicinal plants. Int J Pharm Sci Rev 9:136-145

Albertyn R, Berg A, Numanoglu A, Rode H (2015) Traditional burn care in subSaharan Africa: a long history with wide acceptance. Burns 41:203-211. https://doi.org/10.1016/j.burns.2014.06.005

Alese MO, Adewole SO, Akinwunmi KF, Omonisi AE, Alese OO (2017) Aspirininduced gastric lesions alters EGFR and PECAM-1 immunoreactivity in Wistar rats: modulatory action of flavonoid fraction of Musa paradisiaca. Open Access Maced J Med Sci 5:569

Alese MO, Adewole OS, Ijomone OM, Ofusori DA, Alese OO (2018) Mucus secretion and collagen fibres integrity are compromised in aspirin induced gastric lesion; protective role of Musa paradisiaca. Ital J Anat Embryol 123:136-148

Amaeze OU, Aderemi-Williams Rl, Ayo-Vaughan MA, Ogundemuren DA, Ogunmola DS, Anyika EN (2018) Herbal medicine use among Type 2 diabetes mellitus patients in Nigeria: understanding the magnitude and predictors of use. Int J Clin Pharm 40:580-588. https://doi.org/10. 1007/s11096-018-0648-2

Amutha K, Selvakumari U (2016) Wound healing activity of methanolic stem extract of Musa paradisiaca Linn. (Banana) in Wistar albino rats. Int Wound J 13:763-767

Anbazhagan P et al (2017) Mosquitocidal, antimalarial and antidiabetic potential of Musa paradisiaca-synthesized silver nanoparticles: in vivo and in vitro approaches. J Clust Sci 28:91-107

Anosa GN, Okoro OJ (2011) Anticoccidial activity of the methanolic extract of Musa paradisiaca root in chickens. Trop Anim Health Prod 43:245-248. https://doi.org/10.1007/s11250-010-9684-1

Arun KB, Thomas S, Reshmitha TR, Akhil GC, Nisha P (2017) Dietary fibre and phenolic-rich extracts from Musa paradisiaca inflorescence ameliorates type 2 diabetes and associated cardiovascular risks. J Funct Foods 31:198-207. https://doi.org/10.1016/j.jff.2017.02.001

Arun KB, Madhavan A, Reshmitha TR, Thomas S, Nisha P (2018) Musa paradisjaca inflorescence induces human colon cancer cell death by modulating cascades of transcriptional events. Food Funct 9:511-524

Arun KB, Madhavan A, Reshmitha TR, Thomas S, Nisha P (2019) Short chain fatty acids enriched fermentation metabolites of soluble dietary fibre from Musa paradisiaca drives HT29 colon cancer cells to apoptosis. PLoS ONE 14:e0216604. https://doi.org/10.1371/journal.pone.02166 04

Asoso O, Akharaiyi FC, Animba L (2016) Antibacterial activities of plantain (Musa paradisiaca) peel and fruit. Der Pharm Lett 8:5-11

Asuquo EG, Udobi CE (2016) Antibacterial and toxicity studies of the ethanol extract of Musa paradisiaca leaf. Cogent Biol 2:1219248

Aune D et al (2017) Fruit and vegetable intake and the risk of cardiovascular disease, total cancer and all-cause mortality-a systematic review and dose-response meta-analysis of prospective studies. Int J Epidemiol 46:1029-1056. https://doi.org/10.1093/ije/dyw319

Bagavan A, Rahuman AA, Kaushik NK, Sahal D (2011) In vitro antimalarial activity of medicinal plant extracts against Plasmodium falciparum. Parasitol Res 108:15-22

Behiry SI et al (2019) Antifungal and antibacterial activities of Musa paradisiaca L. peel extract: HPLC analysis of phenolic and flavonoid contents. Processes 7:215 
Bennett RN, Shiga TM, Hassimotto NM, Rosa EA, Lajolo FM, Cordenunsi BR (2010) Phenolics and antioxidant properties of fruit pulp and cell wall fractions of postharvest banana (Musa acuminata Juss.) cultivars. J Agric Food Chem 58:7991-8003

Bhinge SD, Bhutkar M, Randive D, Wadkar G, Jadhav N, Jadhav A, Ingalkar R (2019) Comparative in vitro hypoglycemic studies of unripe, ripe and overripe fruit extract of Musa paradisiaca (Indian banana). Br Food J 121:1236-1247. https://doi.org/10.1108/BFJ-08-2018-0518

Blair JMA, Webber MA, Baylay AJ, Ogbolu DO, Piddock LJV (2015) Molecular mechanisms of antibiotic resistance. Nat Rev Microbiol 13:42-51. https://doi.org/10.1038/nrmicro3380

Boehme MW, Autschbach F, Ell C, Raeth U (2007) Prevalence of silent gastric ulcer, erosions or severe acute gastritis in patients with type 2 diabetes mellitus - a cross-sectional study. Hepatogastroenterology 54:643-648

Bruno LO, Simoes RS, de Jesus SM, Girão MJBC, Grundmann O (2018) Pregnancy and herbal medicines: an unnecessary risk for women's health—a narrative review. Phytother Res 32:796-810. https://doi.org/ 10.1002/ptr.6020

Chabuck ZAG, Al-Charrakh AH, Hindi NKK, Hindi SKK (2013) Antimicrobial effect of aqueous banana peel extract. Iraq Res Gate Pharm Sci 1:73-75

Chatfield K, Salehi B, Sharifi-Rad J, Afshar L (2018) Applying an ethical framework to herbal medicine. Evid Based Complement Altern Med. https:// doi.org/10.1155/2018/1903629

Chokoeva AA, Zisova L, Chorleva K, Tchernev G (2016) Aspergillus niger-a possible new etiopathogenic agent in Tinea capitis? Presentation of two cases. Braz J Infect Dis 20:303-307. https://doi.org/10.1016/j.bjid. 2016.01.002

Chowdhury KAA et al (2016) Cytotoxic and thrombolytic activity of roots of Musa paradisiaca (Linn). Pharma Innov 5:97

Chu S, Tan L, Liu C, Peng H, Duan H, Huang L (2018) Growth rings in roots of medicinal perennial dicotyledonous herbs from temperate and subtropical zones in China. Microsc Res Tech 81:365-375. https://doi. org/10.1002/jemt.22987

Correa M, Mesomo MC, Pianoski KE, Torres YR, Corazza ML (2016) Extraction of inflorescences of Musa paradisiaca L. using supercritical $\mathrm{CO}_{2}$ and compressed propane. J Supercrit Fluids 113:128-135

Debaandya M, Namrata S (2010) Banana and its by-product utilization: an overview. J Sci Ind Res 10:323-329

Do QD, Angkawijaya AE, Tran-Nguyen PL, Huynh LH, Soetaredjo FE, Ismadji S, Ju Y-H (2014) Effect of extraction solvent on total phenol content, total flavonoid content, and antioxidant activity of Limnophila aromatica. J Food Drug Anal 22:296-302. https://doi.org/10.1016/j.jfda.2013.11.001

dos Santos NST et al (2012) Efficacy of the application of a coating composed of chitosan and Origanum vulgare L. essential oil to control Rhizopus stolonifer and Aspergillus niger in grapes (Vitis labrusca L.). Food Microbiol. 32:345-353

Dréno B, Pécastaings S, Corvec S, Veraldi S, Khammari A, Roques C (2018) Cutibacterium acnes (Propionibacterium acnes) and acne vulgaris: a brief look at the latest updates. J Eur Acad Dermatol Venereol 32:5-14

Ehiowemwenguan G, Emoghene A, Inetianbor J (2014) Antibacterial and phytochemical analysis of banana fruit peel. IOSR J Pharm 4:18-25

Ekpete OA, Marcus AC, Osi V (2017) Preparation and characterization of activated carbon obtained from plantain (Musa paradisiaca) fruit stem. J Chem. https://doi.org/10.1155/2017/8635615

Eleazu CO, Iroaganachi M, Eleazu KC (2013) Ameliorative potentials of cocoyam (Colocasia esculenta L.) and unripe plantain (Musa paradisiaca L.) on the relative tissue weights of streptozotocin-induced diabetic rats. J Diabetes Res. https://doi.org/10.1155/2013/160964

Eleazu CO, Eleazu KC, Iroaganachi MA (2016) Effect of cocoyam (Colocasia esculenta), unripe plantain (Musa paradisiaca) or their combination on glycated hemoglobin, lipogenic enzymes, and lipid metabolism of streptozotocin-induced diabetic rats. Pharm Biol 54:91-97

Fahim M et al (2019) TLC-bioautography identification and GC-MS analysis of antimicrobial and antioxidant active compounds in Musa $\times$ paradisiaca L. fruit pulp essential oil. Phytochem Anal 30:332-345. https://doi.org/ 10.1002/pca.2816

Famakin O, Fatoyinbo A, ljarotimi OS, Badejo AA, Fagbemi TN (2016) Assessment of nutritional quality, glycaemic index, antidiabetic and sensory properties of plantain (Musa paradisiaca)-based functional dough meals. J Food Sci Technol 53:3865-3875. https://doi.org/10.1007/ s13197-016-2357-y

Fitz-Gibbon S et al (2013) Propionibacterium acnes strain populations in the human skin microbiome associated with acne. J Investig Dermatol 133:2152-2160

Fongnzossie EF, Tize Z, Fogang Nde PJ, Nyangono Biyegue CF, Bouelet Ntsama IS, Dibong SD, Nkongmeneck BA (2017) Ethnobotany and pharmacognostic perspective of plant species used as traditional cosmetics and cosmeceuticals among the Gbaya ethnic group in Eastern Cameroon. S Afr J Bot 112:29-39. https://doi.org/10.1016/j.sajb.2017.05.013

French GL (2010) The continuing crisis in antibiotic resistance. Int J Antimicrob Agents 36:S3-S7

Galloway AF, Knox P, Krause K (2020) Sticky mucilages and exudates of plants: putative microenvironmental design elements with biotechnological value. New Phytol 225:1461-1469

Gebrehiwot M, Asres K, Bisrat D, Mazumder A, Lindemann P, Bucar F (2015) Evaluation of the wound healing property of Commiphora guidottii Chiov. Ex. Guid. BMC Complement Altern Med 15:282. https://doi.org/ 10.1186/s12906-015-0813-2

Goel RK, Sairam K, Rao CV (2001) Role of gastric antioxidant and anti-Helicobactor pylori activities in antiulcerogenic activity of plantain banana (Musa sapientum var. paradisiaca). Indian J Exp Biol 39:719-722

González-Montelongo R, Lobo MG, González M (2010) The effect of extraction temperature, time and number of steps on the antioxidant capacity of methanolic banana peel extracts. Sep Purif Technol 71:347-355

Gul K, Singh AK, Jabeen R (2016) Nutraceuticals and functional foods: the foods for the future world. Crit Rev Food Sci Nutr 56:2617-2627. https:// doi.org/10.1080/10408398.2014.903384

Hosseinzadeh S, Jafarikukhdan A, Hosseini A, Armand R (2015) The application of medicinal plants in traditional and modern medicine: a review of Thymus vulgaris. Int J Clin Med 6:635-642

Ibukun O, Kade I, Oguntoyinbo T, Ogunmoyole T, Johnson O (2012) Effect of ripening on the phytochemical constituents and antioxidant properties of plantain (Musa paradisiaca). J Med Plant Res 6:5077-5085

Imam MZ, Akter S (2011) Musa paradisiaca L. and Musa sapientum L.: a phytochemical and pharmacological review. J Appl Pharm Sci 1:14-20

Iweala EJ, Obichi IC, Omotosho OE (2011) Biochemical and histological responses of hepatotoxic rats fed Musa paradisiaca L. supplemented diet. Int J Pharmacol 4:471-477

Jaiswal Y, Liang Z, Zhao Z (2016) Botanical drugs in ayurveda and traditional Chinese medicine. J Ethnopharmacol 194:245-259. https://doi.org/10. 1016/j.jep.2016.06.052

Jawla S, Kumar Y, Khan M (2012) Antimicrobial and antihyperglycemic activities of Musa paradisiaca flowers. Asian Pac J Trop Biomed 2:S914-S918

Jiménez-Martínez MC, Montalvo-González E, Sáyago-Ayerdi SG, MercadoMercado G, Ramírez-de León JA, Paz-Gamboa E, Vivar-Vera MA (2017) Effect of high hydrostatic pressure on the polyphenols and antioxidant activity of plantain pulp (Musa paradisiaca AAB). J Sci Food Agric 97:2508-2515. https://doi.org/10.1002/jsfa.8067

Joshi A, Sengar N, Prasad SK, Goel RK, Singh A, Hemalatha S (2013) Woundhealing potential of the root extract of Albizzia lebbeck. Planta Med 79:737-743. https://doi.org/10.1055/s-0032-1328539

Kapadia SP, Pudakalkatti PS, Shivanaikar S (2015) Detection of antimicrobial activity of banana peel (Musa paradisiaca L.) on Porphyromonas gingivalis and Aggregatibacter actinomycetemcomitans: an in vitro study. Contemp Clin Dent 6:496-499. https://doi.org/10.4103/0976-237X. 169864

Kappel VD et al (2013) Beneficial effects of banana leaves (Musa x paradisiaca) on glucose homeostasis: multiple sites of action. Rev Bras Farmacogn 23:706-715

Karadi R, Shah A, Parekh P, Azmi P (2011) Antimicrobial activities of Musa paradisiaca and Cocos nucifera. Int J Pharm 2:264-267

Karuppiah P, Mustaffa M (2013) Antibacterial and antioxidant activities of Musa sp. leaf extracts against multidrug resistant clinical pathogens causing nosocomial infection. Asian Pac JTrop Biomed 3:737-742. https://doi. org/10.1016/S2221-1691(13)60148-3

Khamboonruang P, Anuntasethakul T, Navephap S, LeGrand SM (2015) Evaluation of anti-gastric ulcer activity of ethanolic extract from pseudostem of Musax paradisiaca in experimental animals. Thai J Sci Technol 4:310-320 
Kipkore W, Wanjohi B, Rono H, Kigen G (2014) A study of the medicinal plants used by the Marakwet Community in Kenya. J Ethnobiol Ethnomed 10:24. https://doi.org/10.1186/1746-4269-10-24

Krishnan SSC, Subramanian IP, Subramanian SP (2014) Isolation, characterization of syringin, phenylpropanoid glycoside from Musa paradisiaca tepal extract and evaluation of its antidiabetic effect in streptozotocininduced diabetic rats. Biomed Prev Nutr 4:105-111

Kumar S, Mishra CK, Ahuja A, Rani A, Nema N (2012) Phytoconstituents and pharmacological activities of Musa Paradisiaca Linn. Asian J Pharm 4:199-204

Kumar M, Gautam MK, Singh A, Goel RK (2013) Healing effects of Musa sapientum var. paradisiaca in diabetic rats with co-occurring gastric ulcer: cytokines and growth factor by PCR amplification. BMC Complement Altern Med 13:305. https://doi.org/10.1186/1472-6882-13-305

Lakshmi V et al (2015) An overview of Musa paradisiaca. Linn NPAIJ 11:105-109

Lau BF et al (2020) Banana inflorescence: its bio-prospects as an ingredient for functional foods. Trends Food Sci Technol 97:14-28. https://doi.org/10. 1016/j.tifs.2019.12.023

Lavanya K, Abi Beaulah G, Vani G (2016) Musa Parasidisiaca - a review of phytochemistry and pharmacology. World J Pharm Med Res 2:163-173

Leonti M, Casu L (2013) Traditional medicines and globalization: current and future perspectives in ethnopharmacology. Front Pharmacol 4:92. https://doi.org/10.3389/fphar.2013.00092

Li FS, Weng JK (2017) Demystifying traditional herbal medicine with modern approach. Nat Plants 3:17109. https://doi.org/10.1038/nplants.2017.109

Loganayaki N, Rajendrakumaran D, Manian S (2010) Antioxidant capacity and phenolic content of different solvent extracts from banana (Musa paradisiaca) and mustai (Rivea hypocrateriformis). Food Sci Biotechnol 19:1251-1258. https://doi.org/10.1007/s10068-010-0179-7

Mallick C, Maiti R, Ghosh D (2006) Comparative study on antihyperglycemic and antihyperlipidemic effects of separate and composite extract of seed of Eugenia jambolana and root of Musa paradisiaca in streptozotocin-induced diabetic male Albino rat. Iran J Pharmacol Ther 5:27-33

Martínez-Ruano JA, Caballero-Galván AS, Restrepo-Serna DL, Cardona CA (2018) Techno-economic and environmental assessment of biogas production from banana peel (Musa paradisiaca) in a biorefinery concept. Environ Sci Pollut Res 25:35971-35980. https://doi.org/10.1007/ s11356-018-1848-y

Maruthai J, Muthukumarasamy A, Baskaran B (2018) Fabrication and characterisation of silver nanoparticles using bract extract of Musa paradisiaca for its synergistic combating effect on phytopathogens, free radical scavenging activity, and catalytic efficiency. IET Nanobiotechnol 13:134-143

Mathew NS, Negi PS (2017) Traditional uses, phytochemistry and pharmacology of wild banana (Musa acuminata Colla): a review. J Ethnopharmacol 196:124-140. https://doi.org/10.1016/j.jep.2016.12.009

Meigs JB (2019) The genetic epidemiology of type 2 diabetes: opportunities for health translation. Curr Diab Rep 19:62. https://doi.org/10.1007/ s11892-019-1173-y

Mohammed MA, Alnour TM, Shakurfo OM, Aburass MM (2016) Prevalence and antimicrobial resistance pattern of bacterial strains isolated from patients with urinary tract infection in Messalata Central Hospital, Libya. Asian Pac J Trop Med 9:771-776

Monteiro M et al (2020) Effect of extraction method and solvent system on the phenolic content and antioxidant activity of selected macro-and microalgae extracts. J Appl Phycol 32:349-362

Mulukutla S, Kale TP (2019) Evaluation of polyethylene surgical drape as an alternative wound dressing material, compared to banana leaf (Musa paradisiaca) dressing in facial abrasions. J Oral Maxillofac Surg 3:1-7. https://doi.org/10.1007/s12663-019-01256-3

Murthy S, Gautam M, Goel S, Purohit V, Sharma H, Goel R (2013) Evaluation of in vivo wound healing activity of Bacopa monniera on different wound model in rats. Biomed Res Int 2013:972028

Nadumane VK, Timsina B (2014) Anti-cancer potential of banana flower extract: an in vitro study. Bangladesh J Pharmacol 9:628-635

Naveed M et al (2017) Plant exudates may stabilize or weaken soil depending on species, origin and time. Eur J Soil Sci 68:806-816

Navghare V, Dhawale S (2017) In vitro antioxidant, hypoglycemic and oral glucose tolerance test of banana peels. Alex J Med 53:237-243
Nicolaou KC, Rigol S (2018) A brief history of antibiotics and select advances in their synthesis. J Antibiot 71:153-184. https://doi.org/10.1038/ja.2017. 62

Nirmala M, Girija K, Lakshman K, Divya T (2012) Hepatoprotective activity of Musa paradisiaca on experimental animal models. Asian Pac JTrop Biomed 2:11-15

Nirumand MC, Hajialyani M, Rahimi R, Farzaei MH, Zingue S, Nabavi SM, Bishayee $A$ (2018) Dietary plants for the prevention and management of kidney stones: preclinical and clinical evidence and molecular mechanisms. Int J Mol Sci. https://doi.org/10.3390/ijms19030765

Novak FR, Almeida JA, Silva RS (2003) Banana peel: a possible source of infection in the treatment of nipple fissures. J Pediatr 79:221-226

Nwafor S, Esimone C, Amadi C, Nworu C (2003) In vivo interaction between ciprofloxacin hydrochloride and the pulp of unripe plantain (Musa paradisiaca). Eur J Drug Metab Pharmacokinet 28:253-258

Okorondu S, Akujobi C, Nwachukwu I (2012) Antifungal properties of Musa paradisiaca (Plantain) peel and stalk extracts. Int J Biol Chem Sci 6:1527-1534

Oluwajuyitan TD, ljarotimi OS (2019) Nutritional, antioxidant, glycaemic index and antihyperglycaemic properties of improved traditional plantainbased (Musa AAB) dough meal enriched with tigernut (Cyperus esculentus) and defatted soybean (Glycine max) flour for diabetic patients. Heliyon 5:e01504. https://doi.org/10.1016/j.heliyon.2019.e01504

Onyema C, Ofor C, Okudo V, Ogbuagu A (2016) Phytochemical and antimicrobial analysis of banana pseudo stem (Musa acuminata). J Pharm Res Int 10:1-9

Onyenekwe PC, Okereke OE, Owolewa SO (2013) Phytochemical screening and effect of Musa paradisiaca stem extrude on rat haematological parameters. Curr Res J Biol Sci 5:26-29

Osim EE, Ibu JO (1991) The effect of plantains Musa paradisiaca on DOCA induced hypertension in rats. Int J Pharmacogn Phytochem Res 29:9-13

Oyewole Ol, Akinbamijo TO, Omoboriowo OJ, Ukana NU (2015) Hepatorenal protective activities of plantain root (Musa paradisiaca) on arsenicinduced oxidative damage in rats. Adv Biochem 3:30-34

Oyeyinka BO, Afolayan AJ (2019) Comparative evaluation of the nutritive, mineral, and antinutritive composition of Musa sinensis L. (banana) and Musa paradisiaca L. (plantain) fruit compartments. Plants (basel) 8:598. https://doi.org/10.3390/plants8120598

Oyeyinka BO, Afolayan AJ (2020) Comparative and correlational evaluation of the phytochemical constituents and antioxidant activity of Musa sinensis L. and Musa paradisiaca L. fruit compartments (Musaceae). Sci World J 6:4503824. https://doi.org/10.1155/2020/4503824

Ożarowski M, Mikołajczak P, Kujawski R, Wielgus K, Klejewski A, Wolski H, Seremak-Mrozikiewicz A (2018) Pharmacological effect of quercetin in hypertension and its potential application in pregnancy-induced hypertension: review of in vitro, in vivo, and clinical studies. Evid Based Complement Altern Med. https://doi.org/10.1155/2018/7421489

Padam B, Tin H, Chye F, Abdullah M (2012) Antibacterial and antioxidative activities of the various solvent extracts of banana (Musa paradisiaca cv. Mysore) inflorescences. Int J Biol Sci 12:62-73

Pannangpetch P, Vuttivirojana A, Kularbkaew C, Tesana S, Kongyingyoes B, Kukongviriyapan V (2001) The antiulcerative effect of Musa species in rats. Phytother Res 15(5):407-410

Parmar HS, Kar A (2008) Medicinal values of fruit peels from Citrus sinensis, Punica granatum, and Musa paradisiaca with respect to alterations in tissue lipid peroxidation and serum concentration of glucose, insulin, and thyroid hormones. J Med Food 11:376-381. https://doi.org/10. 1089/jmf.2006.010

Pathak PD, Mandavgane SA, Kulkarni BD (2016) Valorization of banana peel: a biorefinery approach. Rev Chem Eng 32:651. https://doi.org/10.1515/ revce-2015-0063

Patil MVK, Kandhare AD, Bhise SD (2012) Pharmacological evaluation of ethanolic extract of Daucus carota Linn root formulated cream on wound healing using excision and incision wound model. Asian Pac J Trop Biomed 2:S646-S655

Patiño-Rodríguez O, Agama-Acevedo E, Pacheco-Vargas G, Alvarez-Ramirez J, Bello-Pérez LA (2019) Physicochemical, microstructural and digestibility analysis of gluten-free spaghetti of whole unripe plantain flour. Food Chem 298:125085. https://doi.org/10.1016/j.foodchem.2019.125085 
Pelissari FM, Andrade-Mahecha MM, Sobral PJdA, Menegalli FC (2012) Isolation and characterization of the flour and starch of plantain bananas (Musa paradisiaca). Starch-Stärke 64:382-391

Pereira A, Maraschin M (2015) Banana (Musa spp) from peel to pulp: ethnopharmacology, source of bioactive compounds and its relevance for human health. J Ethnopharmacol 160:149-163. https://doi.org/10. 1016/j.jep.2014.11.008

Perry A, Lambert P (2011) Propionibacterium acnes: infection beyond the skin. Expert Rev Anti Infect Ther 9:1149-1156

Pietrzak W, Nowak R, Olech M (2014) Effect of extraction method on phenolic content and antioxidant activity of mistletoe extracts from Viscum album subsp. abietis. Chem Pap 68:976-982. https://doi.org/10.2478/ s11696-013-0524-4

Prakash B, Sumangala CH, Melappa G, Gavimath C (2017) Evaluation of antifungal activity of banana peel against scalp fungi. Mater Today 4:11977-11983. https://doi.org/10.1016/j.matpr.2017.09.119

Priya R, Srivastava S, Singh K, Mathad C, Thind P (2014) Study of antioxidant and antimicrobial properties, phytochemical screening and analysis of sap extracted from banana (Musa acuminata) pseudostem. Int J Adv Biotechnol Res 5:649-658

Rabbani GH, Teka T, Zaman B, Majid N, Khatun M, Fuchs GJ (2001) Clinical studies in persistent diarrhea dietary management with green banana or pectin in Bangladeshian children. Gastroenterology 121:554-560

Raj H, Ghosh D, Banerjee R, Salimath BP (2017) Suppression of VEGF-induced angiogenesis and tumor growth by Eugenia jambolana, Musa paradisiaca, and Coccinia indica extracts. Pharm Biol 55:1489-1499. https://doi. org/10.1080/13880209.2017.1307422

Reddy J, Hemachandran J (2014) Comparative evaluation of the antidiabetic and hypoglycaemic potentials of the parts Musa paradisiaca plant extracts. Int J Sci Res 4:1-5

Rojas JJ, Ochoa VJ, Monoz JF (2006) Screening for antimicrobial activity of ten medicinal plants used in Colombian folkloric medicine: a possible alternative in treatment of nonnosocomial infection. BMC Complement Altern Med 6:1-6

Saravanan K, Aradhya S (2011a) Polyphenols of pseudostem of different banana cultivars and their antioxidant activities. J Agric Food Chem 59:3613-3623

Saravanan K, Aradhya SM (201 1b) Potential nutraceutical food beverage with antioxidant properties from banana plant bio-waste (pseudostem and rhizome). Food Funct 2:603-610

Sartori T, Menegalli FC (2016) Development and characterization of unripe banana starch films incorporated with solid lipid microparticles containing ascorbic acid. Food Hydrocoll 55:210-219

Sasipriya G, Maria CL, Siddhuraju P (2014) Influence of pressure cooking on antioxidant activity of wild (Ensete superbum) and commercial banana (Musa paradisiaca var. Monthan) unripe fruit and flower. J Food Sci Technol 51:2517-2525. https://doi.org/10.1007/s13197-012-0791-z

Savali AS, Bhinge SD, Chitapurkar HR (2011) Evaluation of hair growth promoting activity of Musa paradisiaca unripe fruit extract. J Nat Pharm 2:120-124

Shakib Z, Shahraki N, Razavi BM, Hosseinzadeh H (2019) Aloe vera as an herbal medicine in the treatment of metabolic syndrome: a review. Phytother Res 33:2649-2660. https://doi.org/10.1002/ptr.6465

Shamla L, Nisha P (2017) Acrylamide formation in plantain (Musa paradisiaca) chips influenced by different ripening stages: a correlation study with respect to reducing sugars, amino acids and phenolic content. Food Chem 222:53-60. https://doi.org/10.1016/j.foodchem.2016.12.007

Shanmuga SC, Subramanian S (2012) Musa Paradisiaca flower extract improves carbohydrate metabolism in hepatic tissues of streptozotocin-induced experimental diabetes in rats. Asian Pac J Trop Biomed 2:S1498-S1503. https://doi.org/10.1016/S2221-1691(12)60444-4

Shodehinde SA, Oboh G (2013) Antioxidant properties of aqueous extracts of unripe Musa paradisiaca on sodium nitroprusside induced lipid peroxidation in rat pancreas in vitro. Asian Pac J Trop Biomed 3:449-457. https://doi.org/10.1016/S2221-1691(13)60095-7

Shodehinde SA, Ademiluyi AO, Oboh G, Akindahunsi AA (2015) Contribution of Musa paradisiaca in the inhibition of a-amylase, a-glucosidase and Angiotensin-I converting enzyme in streptozotocin induced rats. Life Sci 133:8-14. https://doi.org/10.1016/j.lfs.2015.03.026
Silva A et al (2014) Activity of cycloartane-type triterpenes and sterols isolated from Musa paradisiaca fruit peel against Leishmania infantum chagasi. Phytomedicine 21:1419-1423

Singh SK, Kesari AN, Rai PK, Watal G (2007) Assessment of glycemic potential of Musa paradisiaca stem juice. Indian J Clin Biochem 22:48-52

Singh B, Singh JP, Kaur A, Singh N (2016) Bioactive compounds in banana and their associated health benefits - a review. Food Chem 206:1-11

Sundaram IK, Sarangi DD, Sundararajan V, George S, Sheik MS (2018) Poly herbal formulation with anti-elastase and anti-oxidant properties for skin anti-aging. BMC Complement Altern Med 18:33. https://doi.org/10. 1186/s12906-018-2097-9

Sunyoto T, Verdonck K, el Safi S, Potet J, Picado A, Boelaert M (2018) Uncharted territory of the epidemiological burden of cutaneous leishmaniasis in sub-Saharan Africa - a systematic review. PLOS Negl Trop Dis 12:e0006914. https://doi.org/10.1371/journal.pntd.0006914

Taha M, Kohnen C, Mallya S, Kou Y, Zapata A, Ramirez-Arcos S (2018) Comparative characterisation of the biofilm-production abilities of Staphylococcus epidermidis isolated from human skin and platelet concentrates. J Med Microbiol 67:190-197. https://doi.org/10.1099/jmm.0.000673

Tanee F, Albert E (2013) Air pollution tolerance indices of plants growing around Umuebulu Gas Flare Station in Rivers State, Nigeria. Afr J Environ Sci Technol 7:1-8

Tekola-Ayele F, Adeyemo AA, Rotimi CN (2013) Genetic epidemiology of type 2 diabetes and cardiovascular diseases in Africa. Prog Cardiovasc Dis 56:251-260. https://doi.org/10.1016/j.pcad.2013.09.013

Thomford NE, Dzobo K, Chimusa E, Andrae-Marobela K, Chirikure S, Wonkam A, Dandara C (2018) Personalized herbal medicine? A roadmap for convergence of herbal and precision medicine biomarker innovations. OMICS 22:375-391. https://doi.org/10.1089/omi.2018.0074

Tilahun B, Worku B, Tachbele E, Terefe S, Kloos H, Legesse W (2012) High load of multi-drug resistant nosocomial neonatal pathogens carried by cockroaches in a neonatal intensive care unit at Tikur Anbessa specialized hospital, Addis Ababa, Ethiopia. Antimicrob Resist Infect Control 1:12

Tran QB, Phenrat T, Lohitnavy M (2019) Physiologically based pharmacokinetic modeling of hydrogen cyanide in humans following the oral administration of potassium cyanide and cyanogenic glycosides from food. Hum Ecol Risk Assess 26:1496-1511

Tsamo CVP, Andre CM, Ritter C, Tomekpe K, Ngoh Newilah G, Rogez H, Larondelle Y (2014) Characterization of Musa sp. fruits and plantain banana ripening stages according to their physicochemical attributes. J Agric Food Chem 62:8705-8715. https://doi.org/10.1021/jf5021939

Tsamo CVP et al (2015) Phenolic profiling in the pulp and peel of nine plantain cultivars (Musa sp.). Food Chem 167:197-204

Ugbogu EA, Ude VC, Elekwa I, Arunsi UO, Uche-Ikonne C, Nwakanma C (2018) Toxicological profile of the aqueous-fermented extract of Musa paradisiaca in rats. Avicenna J Phytomed 8:478-487

United States Department of Agriculture (USDA) (2018) Basic reports 09542: plantain, green, raw. Nutrient Database for Standard Reference Legacy Release. https://data.nal.usda.gov/dataset/usda-national-nutrient-datab ase-standard-reference-legacy-release. Accessed 21 Sept 2020

Vadivelan R, Elango K, Suresh B, Ramesh BR (2006) Pharmacological validation of Musa paradisiaca Bhasma for antiulcer activity in albino rats-a preliminary study. Anc Sci Life 25:67-70

Verpoorte DR (2017) New times for traditional medicine research. J Ethnopharmacol 197:1. https://doi.org/10.1016/j.jep.2017.01.018

Vijayakumar S, Presanna K, Vijayalakshmi NR (2008) Antioxidant activity of banana flavonoids. Fitoterapia 79:279-282

Vijayakumar S et al (2017) Therapeutic effects of gold nanoparticles synthesized using Musa paradisiaca peel extract against multiple antibiotic resistant Enterococcus faecalis biofilms and human lung cancer cells (A549). Microb Pathog 102:173-183. https://doi.org/10.1016/j.micpath. 2016.11.029

Vilhena RO, Fachi MM, Marson BM, Dias BL, Pontes FL, Tonin FS, Pontarolo R (2018) Antidiabetic potential of Musa spp. inflorescence: a systematic review. J Pharm Pharmacol 70:1583-1595

Vilhena RO, Marson BM, Budel JM, Amano E, Messias-Reason IJDT, Pontarolo $R$ (2019) Morpho-anatomy of the inflorescence of Musa $\times$ paradisiaca. Rev Bras Farmacogn 29:147-151

Vilhena RO et al (2020) Antidiabetic activity of Musa x paradisiaca extracts in streptozotocin-induced diabetic rats and chemical characterization 
by HPLC-DAD-MS. J Ethnopharmacol 254:112666. https://doi.org/10. 1016/j.jep.2020.112666

Vu HT, Scarlett CJ, Vuong QV (2018) Phenolic compounds within banana peel and their potential uses: a review. J Funct Foods 40:238-248. https:// doi.org/10.1016/j.jff.2017.11.006

Waszkowiak K, Gliszczyńska-Świgło A, Barthet V, Skręty J (2015) Effect of extraction method on the phenolic and cyanogenic glucoside profile of flaxseed extracts and their antioxidant capacity. J Am Oil Chem' Soc 92:1609-1619. https://doi.org/10.1007/s11746-015-2729-x

Weremfo A, Adinortey MB, Pappoe AN (2011) Haemostatic effect of the stem juice of Musa paradisiaca L (Musaceae) in Guinea pigs. Adv Biol Res 5:190-192

World Health Organization (2013) WHO Traditional Medicine Strategy: 20142023. World Health Organization Press, pp 15-18

Yakubu MT et al (2015) Antidiarrhoeal activity of Musa paradisiaca Sap in Wistar rats. Evid Based Complement Altern Med. https://doi.org/10. $1155 / 2015 / 683726$
Zhang C, Yu X, Ayre BG, Turgeon R (2012) The origin and composition of cucurbit "phloem" exudate. Plant Physiol 158:1873-1882

Zhang J, Onakpoya IJ, Posadzki P, Eddouks M (2015) The safety of herbal medicine: from prejudice to evidence. Evid Based Complement Altern Med. https://doi.org/10.1155/2015/316706

Zhang $\mathrm{H}$ et al (2017) Update of incidence and antimicrobial susceptibility trends of Escherichia coli and Klebsiella pneumoniae isolates from Chinese intra-abdominal infection patients. BMC Infect Dis 17:776. https:// doi.org/10.1186/s12879-017-2873-z

Zimmermann MR, Hafke JB, Van Bel AJ, Furch AC (2013) Interaction of xylem and phloem during exudation and wound occlusion in Cucurbita maxima. Plant Cell Environ 36:237-247

\section{Publisher's Note}

Springer Nature remains neutral with regard to jurisdictional claims in published maps and institutional affiliations.

\section{Submit your manuscript to a SpringerOpen ${ }^{\circ}$ journal and benefit from:}

- Convenient online submission

- Rigorous peer review

- Open access: articles freely available online

- High visibility within the field

- Retaining the copyright to your article

Submit your next manuscript at $\boldsymbol{\nabla}$ springeropen.com 